\title{
Methane mitigation potential of 3-nitrooxypropanol in lactating cows is influenced by basal diet composition
}

\author{
Sanne van Gastelen, ${ }^{1 *}$ ๑ Jan Dijkstra, ${ }^{2} \odot$ Jeroen M. L. Heck, ${ }^{3} \odot$ Maik Kindermann, ${ }^{4} \odot$ Arie Klop, ${ }^{1}{ }^{\oplus}$ \\ Rudi de Mol, ${ }^{1}{ }^{\oplus}$ Dennis Rijnders, ${ }^{4}$ Nicola Walker, ${ }^{4}$ and André Bannink ${ }^{1}$ (i) \\ ${ }^{1}$ Wageningen Livestock Research, Wageningen University \& Research, PO Box 338, $6700 \mathrm{AH}$, Wageningen, the Netherlands \\ ${ }^{2}$ Animal Nutrition Group, Wageningen University \& Research, PO Box 338, $6700 \mathrm{AH}$, Wageningen, the Netherlands \\ ${ }^{3}$ Friesland Campina, PO Box 1551, 3800 BN, Amersfoort, the Netherlands \\ ${ }^{4}$ DSM Nutritional Products, Animal Nutrition \& Health, PO Box 2676, 4002 Basel, Switzerland
}

\section{ABSTRACT}

The objective of this study was to investigate whether the $\mathrm{CH}_{4}$ mitigation potential of 3-nitrooxypropanol (3-NOP) in dairy cattle was affected by basal diet (BD) composition. The experiment involved 64 Holstein-Friesian dairy cows $(146 \pm 45 \mathrm{~d}$ in milk at the start of trial; mean $\pm \mathrm{SD}$ ) in 2 overlapping crossover trials, each consisting of 2 measurement periods. Cows were blocked according to parity, $\mathrm{d}$ in milk, and milk yield, and randomly allocated to 1 of 3 diets: a grass silage-based diet (GS) consisting of $30 \%$ concentrates and $70 \%$ grass silage (DM basis), a grass silage- and corn silage-mixed diet (GSCS) consisting of 30\% concentrates, $42 \%$ grass silage, and $28 \%$ corn silage (DM basis), or a corn silage-based diet (CS) consisting of $30 \%$ concentrates, $14 \%$ grass silage, and $56 \%$ corn silage (DM basis). Two types of concentrates were formulated, viz. a concentrate for the GS diet and a concentrate for the CS diet, to meet the energy and protein requirements for maintenance and milk production. The concentrate for the GSCS diet consisted of a 50:50 mixture of both concentrates. Subsequently, the cows within each type of $\mathrm{BD}$ received 2 treatments in a crossover design: either $60 \mathrm{mg}$ of $3-\mathrm{NOP} / \mathrm{kg}$ of $\mathrm{DM}$ (NOP60) and a placebo with $0 \mathrm{mg}$ of $3-\mathrm{NOP} / \mathrm{kg}$ of DM (NOP0) in one crossover or $80 \mathrm{mg}$ of $3-\mathrm{NOP} /$ $\mathrm{kg}$ of DM (NOP80) and NOP0 in the other crossover. Diets were provided as total mixed ration in feed bins, which automatically recorded feed intake. Additional concentrate was fed in the GreenFeed system that was used to measure emissions of $\mathrm{CH}_{4}$ and $\mathrm{H}_{2}$. The $\mathrm{CS}$ diets resulted in a reduced $\mathrm{CH}_{4}$ yield $\left(\mathrm{g} / \mathrm{kg}\right.$ DMI) and $\mathrm{CH}_{4}$ intensity $(\mathrm{g} / \mathrm{kg}$ milk). Feeding 3 -NOP resulted in a decreased DMI. Milk production and composition did not differ between NOP60 and NOP0, whereas milk

Received May 24, 2021.

Accepted December 20, 2021.

*Corresponding author: sanne.vangastelen@wur.nl yield and the yield of major components decreased for NOP80 compared with NOP0. Feed efficiency was not affected by feeding 3-NOP. Interactions between BD and supplementation of $3-\mathrm{NOP}$ were observed for the production $(\mathrm{g} / \mathrm{d})$ and yield $\left(\mathrm{g} / \mathrm{kg}\right.$ DMI) of both $\mathrm{CH}_{4}$ and $\mathrm{H}_{2}$, indicating that the mitigating effect of 3-NOP depended on the composition of the BD. Emissions of $\mathrm{CH}_{4}$ decreased upon 3-NOP supplementation for all $\mathrm{BD}$, but the decrease in $\mathrm{CH}_{4}$ emissions was smaller for GS $\left(-26.2 \%\right.$ for NOP60 and $-28.4 \%$ for NOP 80 in $\mathrm{CH}_{4}$ yield) compared with both GSCS ( $-35.1 \%$ for NOP60 and $-37.9 \%$ for $\mathrm{NOP} 80$ for $\mathrm{CH}_{4}$ yield) and $\mathrm{CS}(-34.8 \%$ for NOP60 and $-41.6 \%$ for NOP80 for $\mathrm{CH}_{4}$ yield), with no difference between the latter 2 BD. Emissions of $\mathrm{H}_{2}$ increased upon 3-NOP supplementation for all $\mathrm{BD}$, but the $\mathrm{H}_{2}$ yield (g/kg DMI) increased 3.16 and 3.30-fold, respectively, when NOP60 and NOP80 were supplemented to GS, and 4.70 and 4.96 fold, respectively, when NOP60 and NOP80 were supplemented to CS. In conclusion, 3-NOP can effectively decrease $\mathrm{CH}_{4}$ emissions in dairy cows across diets, but the level of $\mathrm{CH}_{4}$ mitigation is greater when supplemented in a corn silage-based diet compared with a grass silage-based diet.

Key words: dairy cattle, methanogen inhibitor, feed additive, silage-based diet

\section{INTRODUCTION}

Enteric $\mathrm{CH}_{4}$ production is among the main targets of greenhouse gas mitigation practices for the dairy industry (Hristov et al., 2013), and multiple comprehensive reviews on enteric $\mathrm{CH}_{4}$ mitigation strategies have been published (e.g., Beauchemin et al., 2008; Martin et al., 2010; Hristov et al., 2013). Several dietary strategies have been proposed to mitigate enteric $\mathrm{CH}_{4}$ production, including improvement of forage quality, feeding different forage types, supplementing lipids, and using feed additives. Duin et al. (2016) described the characteristics of the feed additive 3-nitrooxypropanol (3-NOP). 
By molecular docking of 3-NOP at the site of methylcoenzyme M binding, 3-NOP specifically targets the nickel enzyme, methyl-coenzyme $\mathrm{M}$ reductase, which catalyzes the last step in the $\mathrm{CH}_{4}$-forming pathway of rumen archaea (Duin et al., 2016). Several studies have investigated the effects of $3-\mathrm{NOP}$ on $\mathrm{CH}_{4}$ emission in dairy cattle (e.g., Hristov et al., 2015a; Lopes et al., 2016; van Gastelen et al., 2020). In a recent study, where the efficacy of several dietary strategies across studies and between different ruminant types was compared, van Gastelen et al. (2019) concluded that 3-NOP was an effective $\mathrm{CH}_{4}$ mitigating feed additive for dairy cattle. This conclusion was based on the unaffected DMI with substantial reductions in $\mathrm{CH}_{4}$ production $(\mathrm{g} / \mathrm{d}$; on average mitigated by $35 \%), \mathrm{CH}_{4}$ yield $(\mathrm{g} /$ $\mathrm{kg}$ of DMI; on average mitigated by $35 \%$ ), and $\mathrm{CH}_{4}$ intensity ( $\mathrm{g} / \mathrm{kg}$ of milk; on average mitigated by $25 \%$ ) across studies. The $\mathrm{CH}_{4}$ mitigating effect of $3-\mathrm{NOP}$ is also persistent throughout the early lactation period, starting from onset of lactation until 105 (Melgar et al., 2020b) or 115 DIM (van Gastelen et al., 2020) and in later lactation for 12 (Hristov et al., 2015a) or $15 \mathrm{wk}$ (Melgar et al., 2021).

However, variation in the $\mathrm{CH}_{4}$ mitigating response to the addition of 3 -NOP has been reported across dairy cattle studies; namely, a decrease of between 29\% (Hristov et al., 2015a) and 16\% (van Gastelen et al., 2020) in $\mathrm{CH}_{4}$ yield (g/ $\mathrm{kg}$ of DMI) for a dosage of $60 \mathrm{mg}$ of $3-\mathrm{NOP} / \mathrm{kg}$ of DM compared with a control diet. In a recent meta-analysis, Dijkstra et al. (2018) quantitatively evaluated factors that could explain heterogeneity in the response to 3-NOP. It was concluded that the $\mathrm{CH}_{4}$ mitigation effect of 3-NOP increased with increasing 3-NOP dose and decreased with increasing dietary NDF content, whereas other dietary composition variables, such as dietary forage proportion and $\mathrm{CP}$ content, were not related to the efficacy of 3-NOP (Dijkstra et al., 2018). Vyas et al. (2018) reported a greater $\mathrm{CH}_{4}$ mitigating response in beef cattle when 3 -NOP was supplemented to high-grain diets than to high-forage diets, and suggested that this was due to dietary starch content and subsequently ruminal starch fermentation. Starch fermentation generally results in a low ruminal pH (Van Kessel and Russell, 1996), which has an inhibiting effect on the number of protozoa and methanogens (Grainger and Beauchemin, 2011), subsequently resulting in a lower concentration of methylcoenzyme $\mathrm{M}$ reductase, reduced fiber digestion and consequently the amount of $\mathrm{CH}_{4}$ produced on a daily basis. Hence, adding 3-NOP to high-starch diets might inhibit methyl-coenzyme $\mathrm{M}$ reductase with greater efficacy compared with low-starch diets, potentially resulting in a greater mitigation potential of 3-NOP in high-starch diets. This suggests that the composition of the basal diet (BD) might affect the $\mathrm{CH}_{4}$ mitigation potential of 3-NOP. However, the effect of dietary composition has not been explored previously for dairy cattle receiving 3-NOP. The objective of this study was therefore to investigate whether the $\mathrm{CH}_{4}$ mitigation potential of 3 -NOP in dairy cattle is affected by $\mathrm{BD}$ composition. We hypothesized that 3-NOP supplementation to a corn silage-based diet would result in a greater $\mathrm{CH}_{4}$ mitigating response than when $3-\mathrm{NOP}$ is supplemented to a grass silage-based diet.

\section{MATERIALS AND METHODS}

\section{Experimental Design}

The experiment was conducted from November 2019 to February 2020 at the research facilities Dairy Campus (Wageningen Livestock Research, Leeuwarden, the Netherlands). The use of 3-NOP (DSM Nutritional Products Ltd.) in animal feed was preapproved by the Veterinary Drugs Directorate Division (Utrecht, the Netherlands), and no withdrawal period was implemented.

The experiment involved 64 Holstein-Friesian dairy cows (146 \pm 45 DIM at the start of trial; mean \pm SD). Of the 64 dairy cows, 18 were first-lactation cows, 18 cows were in their second lactation, and 28 cows in their third lactation or higher. The cows were blocked according to parity, DIM, and milk yield, resulting in 11 blocks in total, with 10 blocks of 6 cows and 1 block of 4 cows. One block contained only 4 cows instead of 6 , because we could not enroll 66 dairy cows (11 blocks of 6 cows) due to the restrictions of the barn (e.g., number of lying cubicles and feeding places) and we preferred to enroll the greatest number of dairy cows possible (i.e., 64 instead of only 60 dairy cows). Within each block, cows were randomly allocated to 1 of the 3 experimental BD and to a 3 -NOP dose sequence.

\section{Dietary Treatments}

The experiment started with a covariate period, during which all cows received the same BD according to standard operating procedures at the experimental facilities, consisting of $42 \%$ grass silage, $28 \%$ corn silage, and $30 \%$ concentrates on a DM basis. This diet contained $151 \mathrm{~g}$ of protein $/ \mathrm{kg}$ of DM, $167 \mathrm{~g}$ of starch/ $\mathrm{kg}$ of $\mathrm{DM}$, and $369 \mathrm{~g}$ of $\mathrm{NDF} / \mathrm{kg}$ of DM. After the covariate period, the cows were assigned to an experimental BD. The chemical composition of the individual feed ingredients is presented in Table 1. The ingredient and chemical composition of the experimental BD are presented in Table 2. The targeted compositions of the $\mathrm{BD}$ were as follows (all on a DM basis); $30 \%$ concen- 
Table 1. Chemical composition ( $\mathrm{g} / \mathrm{kg}$ of DM, unless otherwise stated) of the individual feed ingredients

\begin{tabular}{|c|c|c|c|c|c|c|c|c|}
\hline Item & $\begin{array}{l}\text { Grass } \\
\text { silage }^{1}\end{array}$ & $\begin{array}{l}\text { Corn } \\
\text { silage }^{2}\end{array}$ & $\begin{array}{c}\text { Concentrate } \\
\text { GS }^{3}\end{array}$ & $\begin{array}{c}\text { Concentrate } \\
\text { CS }^{4}\end{array}$ & $\begin{array}{l}\text { Premix } \\
\text { NOP0 }\end{array}$ & $\begin{array}{l}\text { Premix } \\
{\text { NOP } 60^{6}}^{6}\end{array}$ & 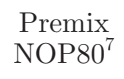 & $\begin{array}{c}\text { GreenFeed } \\
\text { bait }^{8}\end{array}$ \\
\hline DM (g/kg of product) & 358 & 354 & 876 & 886 & 878 & 876 & 876 & 879 \\
\hline $\mathrm{OM}$ & 883 & 954 & 943 & 907 & 930 & 929 & 928 & 924 \\
\hline Crude fat & 37 & 30 & 32 & 31 & 33 & 29 & 31 & 30 \\
\hline Gross energy $(\mathrm{MJ} / \mathrm{kg}$ of $\mathrm{DM})$ & 19.0 & 18.7 & 18.2 & 18.6 & 18.6 & 18.6 & 18.6 & 17.8 \\
\hline NDF & 380 & 365 & 200 & 236 & 213 & 216 & 213 & 362 \\
\hline Starch & $-^{9}$ & 368 & 373 & 15 & 212 & 208 & 206 & 103 \\
\hline Sugar & 85 & ${ }^{9}$ & 92 & 141 & 121 & 115 & 116 & 110 \\
\hline $\mathrm{NE}_{\mathrm{L}}^{10}(\mathrm{MJ} / \mathrm{kg}$ of $\mathrm{DM})$ & 6.6 & 6.8 & 7.8 & 7.4 & 6.7 & 6.7 & 6.7 & 7.0 \\
\hline $\mathrm{DVE}^{11}$ & 61 & 52 & 121 & 159 & 92 & 92 & 92 & 86 \\
\hline $\mathrm{OEB}^{12}$ & 52 & -47 & -23 & 112 & 0 & 0 & 0 & -6 \\
\hline
\end{tabular}

${ }^{1}$ Ensiling characteristics: acetic acid $=18 \mathrm{~g} / \mathrm{kg}$ of DM, lactic acid $=81 \mathrm{~g} / \mathrm{kg}$ of DM, ammonia-n $=7 \%$ total $\mathrm{N}$, and $\mathrm{pH}=4.1$.

${ }^{2}$ Ensiling characteristics: acetic acid $=20 \mathrm{~g} / \mathrm{kg}$ of DM, lactic acid $=68 \mathrm{~g} / \mathrm{kg}$ of DM, ammonia-n $=10 \%$ total $\mathrm{N}$, and $\mathrm{pH}=3.7$.

${ }^{3} \mathrm{GS}=$ grass silage. Ingredient composition $(\mathrm{g} / \mathrm{kg} \mathrm{DM}):$ corn $=360$, rumen-protected rapeseed meal (MervoBest, Nuscience) $=252$, wheat $=$ 214 , sugarbeet pulp $=174$.

${ }^{4} \mathrm{CS}=$ corn silage-based diet. Ingredient composition $(\mathrm{g} / \mathrm{kg} \mathrm{DM})$ : rapeseed meal $=450$, soybean meal $=330$, sugarbeet pulp $=220$.

${ }^{5} \mathrm{NOP} 0=0 \mathrm{mg}$ of $3-\mathrm{NOP} / \mathrm{kg}$ of DM. Ingredient $(\mathrm{g} / \mathrm{kg} \mathrm{DM})$ : rapeseed meal $=222$, sugarbeet pulp $=191$, corn $=180$, soybean meal $=163$, rumen-protected rapeseed meal (MervoBest, Nuscience) $=124$, wheat $=105$, supplement $=16$. The supplement consisted of $100 \%$ placebo supplement.

${ }^{6} \mathrm{NOP} 60=60 \mathrm{mg}$ of $3-\mathrm{NOP} / \mathrm{kg}$ of DM. Ingredient $(\mathrm{g} / \mathrm{kg} \mathrm{DM}):$ rapeseed meal $=222$, sugarbeet pulp $=191$, corn $=180$, soybean meal $=163$, rumen-protected rapeseed meal (MervoBest, Nuscience) $=124$, wheat $=105$, supplement $=16$. The supplement consisted of $25 \%$ placebo supplement $+75 \% 3$-NOP supplement.

${ }^{7} \mathrm{NOP} 80=80 \mathrm{mg}$ of $3-\mathrm{NOP} / \mathrm{kg}$ of DM. Ingredient $(\mathrm{g} / \mathrm{kg} \mathrm{DM}):$ rapeseed meal $=222$, sugarbeet pulp $=191$, corn $=180$, soybean meal $=163$, rumen-protected rapeseed meal (MervoBest, Nuscience) $=124$, wheat $=105$, supplement $=16$. The supplement consisted of $100 \% 3$-NOP supplement.

${ }^{8}$ Ingredient composition $(\mathrm{g} / \mathrm{kg} \mathrm{DM})$ : sugarbeet pulp $=300$, soybean meal $=221$, corn gluten meal $=87$, wheat $=72$, alfalfa $=70$, sunflower meal $=70$, molasses $=50$, barley $=50$, corn $=49$, rapeseed meal $=21, \mathrm{NaCl}=10$.

${ }^{9}$ Not determined.

${ }^{10}$ Van Es, 1978.

${ }^{11}$ Intestinal digestible protein (Van Duinkerken et al., 2011).

${ }^{12}$ Rumen-degradable protein balance (Van Duinkerken et al., 2011).

trates and $70 \%$ grass silage for the grass silage-based diet (GS); $30 \%$ concentrates, $42 \%$ grass silage, and $28 \%$ corn silage for the grass silage- and corn silagemixed diet (GSCS); and 30\% concentrates, $14 \%$ grass silage, and $56 \%$ corn silage for the corn silage-based diet (CS). The chop length of grass silage was $15 \mathrm{~mm}$ and that of corn silage $7 \mathrm{~mm}$, for all BD. To each of these diets, water was added to target a DM content of $400 \mathrm{~g} / \mathrm{kg}$ to enhance feed intake. The concentrate meals (i.e., concentrate GS and concentrate CS) were designed by Agrifirm (Apeldoorn, the Netherlands; Table 1) to meet the requirements for maintenance and milk production [i.e., net energy for lactation (Van Es, 1978); intestinal digestible protein and rumen degraded protein balance (Van Duinkerken et al., 2011)] of the dairy cows on the complete ration level. Hence, 2 types of concentrates were used: a concentrate for the GS diet and a concentrate for the CS diet. The concentrate for the GSCS diet consisted of a 50:50 mixture of both concentrates. The cows were assigned to 1 of the 3 basal experimental diets and received this diet from the start of the adaptation period until the end of the experiment, supplemented with variable doses of 3-NOP.

All 3 BD were subsequently supplemented with 3 different dosages of 3-NOP: a placebo (i.e., silicon dioxide $+1,2$ propanediol; NOP0), 3-NOP (i.e., $10 \% 3$-NOP on silicon dioxide $+1,2$-propanediol) with a target inclusion level of $60 \mathrm{mg} 3-\mathrm{NOP} / \mathrm{kg}$ of DM (NOP60), and 3 -NOP (i.e., $10 \% 3$-NOP on silicon dioxide + 1,2-propanediol) with a target inclusion level of $80 \mathrm{mg}$ $3-\mathrm{NOP} / \mathrm{kg}$ DM (NOP80). To achieve the 3-NOP inclusion levels, $15 \%$ of the concentrates was replaced by a premix containing 3-NOP (Table 2). These premixes were in meal form, produced by Research Diet Services (RDS BV, Wijk bij Duurstede, the Netherlands), and contained either only the placebo supplement for NOP0, a mixture of the placebo supplement (25\%) and 3 -NOP $(75 \%)$ for NOP60, or only 3-NOP for NOP80 (Table 1). By using this approach, the same amount of supplement could be added to the different premixes and achieve a different 3-NOP dose. Also, to achieve the target 3-NOP inclusion levels, we corrected for a 
Table 2. Ingredient and chemical composition ( $\mathrm{g} / \mathrm{kg}$ of DM, unless otherwise stated) of the treatments, where the GreenFeed bait is not included in the calculation of the chemical composition of the treatments ${ }^{1}$

\begin{tabular}{|c|c|c|c|c|c|c|c|c|c|}
\hline \multirow[b]{2}{*}{ Composition } & \multicolumn{3}{|c|}{ GS } & \multicolumn{3}{|c|}{ GSCS } & \multicolumn{3}{|c|}{ CS } \\
\hline & NOP0 & NOP60 & NOP80 & NOP0 & NOP60 & NOP80 & NOP0 & NOP60 & NOP 80 \\
\hline Grass silage & 700 & 701 & 699 & 425 & 427 & 425 & 145 & 146 & 145 \\
\hline Corn silage & 0 & 0 & 0 & 267 & 267 & 267 & 545 & 545 & 544 \\
\hline Concentrate GS & 256 & 255 & 257 & 131 & 130 & 131 & 0 & 0 & 0 \\
\hline Concentrate CS & 0 & 0 & 0 & 132 & 131 & 132 & 264 & 263 & 265 \\
\hline Premix NOP80 & 0 & 0 & 44 & 0 & 0 & 45 & 0 & 0 & 46 \\
\hline \multicolumn{10}{|l|}{ Chemical composition } \\
\hline $\mathrm{DM}$ (g/kg of product) & 397 & 398 & 395 & 391 & 392 & 389 & 382 & 383 & 381 \\
\hline $\mathrm{OM}$ & 901 & 901 & 900 & 915 & 915 & 914 & 930 & 930 & 930 \\
\hline $\mathrm{CP}$ & 196 & 195 & 197 & 186 & 185 & 186 & 174 & 173 & 174 \\
\hline Crude fat & 36 & 36 & 36 & 34 & 33 & 34 & 31 & 31 & 31 \\
\hline Gross energy (MJ/kg of DM) & 18.8 & 18.8 & 18.8 & 18.7 & 18.7 & 18.7 & 18.7 & 18.7 & 18.7 \\
\hline $\mathrm{NE}_{\mathrm{L}}{ }^{2}(\mathrm{MJ} / \mathrm{kg}$ of $\mathrm{DM})$ & 6.9 & 6.9 & 6.9 & 6.8 & 6.8 & 6.8 & 6.7 & 6.7 & 6.7 \\
\hline $\mathrm{DVE}^{3}$ & 78 & 78 & 78 & 79 & 79 & 79 & 81 & 81 & 81 \\
\hline $\mathrm{OEB}^{4}$ & 31 & 31 & 31 & 21 & 21 & 21 & 11 & 11 & 11 \\
\hline
\end{tabular}

${ }^{1} \mathrm{GS}=$ grass silage-based diet; $\mathrm{CS}=$ corn silage-based diet; GSCS = grass silage- and corn silage-mixed diet; NOP0 = $0 \mathrm{mg}$ of 3-NOP $/ \mathrm{kg}$ of DM; $\mathrm{NOP} 60=60 \mathrm{mg}$ of $3-\mathrm{NOP} / \mathrm{kg}$ of DM; NOP80 $=80 \mathrm{mg}$ of $3-\mathrm{NOP} / \mathrm{kg}$ of DM.

${ }^{2}$ Van Es, 1978.

${ }^{3}$ Intestinal digestible protein (Van Duinkerken et al., 2011).

${ }^{4}$ Rumen-degraded protein balance (Van Duinkerken et al., 2011).

pre-experiment estimated intake of $1.11 \mathrm{~kg} / \mathrm{cow} / \mathrm{d}$ of nonsupplemented bait pellets in the GreenFeed stations and an estimated total DMI (i.e., bait and TMR) of $22 \mathrm{~kg}$ of $\mathrm{DM} / \mathrm{d}$. Hence, the targeted 3-NOP inclusion levels in the diets were slightly greater (i.e., 63 instead of $60 \mathrm{mg}$ of $3-\mathrm{NOP} / \mathrm{kg}$ of DM, and 84 instead of $80 \mathrm{mg}$ of $3-\mathrm{NOP} / \mathrm{kg}$ of DM) to achieve an overall target inclusion level of 60 and $80 \mathrm{mg}$ of $3-\mathrm{NOP} / \mathrm{kg}$ of $\mathrm{DM}$ on total DMI including intake of the GreenFeed bait.

\section{Timeline Experiment}

The experiment started with a covariate period of 2 wk in which baseline measurements took place. After the covariate period, animals were adapted to their assigned BD without 3-NOP supplementation (i.e., GS, GSCS, or CS) for a week. The dosages of 3-NOP were subsequently arranged in 2 crossovers, because it was possible to mix only 2 doses of 3 -NOP in the barn at any time point (i.e., 6 different diets). To have NOP0 present always, the second dose was either NOP60 and NOP80. The 3-NOP dose sequence was therefore initiated with NOP0 and NOP60, consisting of an adaptation period of $2 \mathrm{wk}$, followed by a measurement period of wk 1 (i.e., crossover 1, period 1; Figure 1). Then the cows that received NOP0 continued as such, whereas the cows that received NOP60 were switched to NOP80. Cows were adapted to the new 3 -NOP dose for $1 \mathrm{wk}$, after which a new 1-wk measurement period started (crossover 2, period 1). The above time-sequence took place once more to complete the experiment and retrieve the second measurement period of each crossover (Figure 1).

The length of the adaptation periods varied and depended on the change in 3-NOP dose. When the change in 3-NOP dose was relatively large (i.e., from no 3-NOP supplementation to NOP60 or from NOP0 to NOP80 and vice versa), we incorporated a 2 -wk adaptation period. When the change in 3 -NOP dose was relatively small (i.e., from NOP60 to NOP80 and vice versa), we incorporated a 1-wk adaptation period.

\section{Feeding and Housing}

The cows were fed by using an automated feeding system, consisting of the Trioliet feed mixing robot (Triomatic HP 2 300, Trioliet) for mixing the experimental diets, and Insentec feed bins (FB; RIC system, Hokofarm Group BV) to measure feed intake for each individual cow. The Trioliet mixed all experimen- 
tal diets ( $\mathrm{n}=6$ during the measurement periods) 3 times daily in equal portions. Measures to avoid crosscontamination were taken by first mixing the placebo containing treatments (NOP0), followed by a rinsing diet (which was not fed to the cows in the experiment), then mixing the 3-NOP containing treatments (NOP60 or NOP80), followed again by a rinsing diet (which was again not fed to the cows in the experiment). This was repeated 3 times daily.

The different dietary components were stored in bunkers (used for forages), silos (used for concentrates), and mini-silos (used for premixes). The operator of the system determined on a weekly basis (based on the DM content from the previous week of each individual dietary component, measured daily) how much of each of these components was required to prepare the experimental diets. The dietary components were taken automatically from their bunker, silo or mini-silo, weighed, and transported into the Trioliet feed mixing robot. The bunkers and silos, in which the forages and concentrate were respectively stored, could weigh with an accuracy of $\pm 2 \mathrm{~kg}$ of product. The mini-silos, in which the premixes were stored, could weigh with an accuracy of $\pm 2 \mathrm{~g}$ of product. The order in which the dietary components were added to the Trioliet was grass silage, premix portion 1, concentrates, water, premix portion 2 , and corn silage (if applicable). The premixes (containing 3-NOP) were added to the Trioliet in 2 equal portions while mixing was ongoing to achieve a greater homogeneity of 3-NOP in the complete mixture. After the last dietary component was added to the Trioliet, the experimental diets were mixed for an extra $10 \mathrm{~min}$ and transported to the FB. The Trioliet recorded the weight of the dietary components that were added to the experimental diets, as well as the amount that was distributed across the FB. The experimental diets were offered at $10 \%$ excess to the ad libitum feed intake. To achieve this, the amount of experimental diet provided by the Trioliet to the FB was determined daily, taking into account the amount of feed provided the previous day in combination with the feed orts remaining in the FB in the morning (before first feed provided).

The dairy cows were housed as one group in a freestall barn with 64 cubicles, $32 \mathrm{FB}$ for feeding (i.e., 1 FB for 2 cows), and 3 GreenFeed units (C-Lock Inc.) for $\mathrm{CH}_{4}$ and $\mathrm{H}_{2}$ measurements. The assignment of the cows to the FB was established at the start of trial and remained similar throughout the trial. Hence, upon a

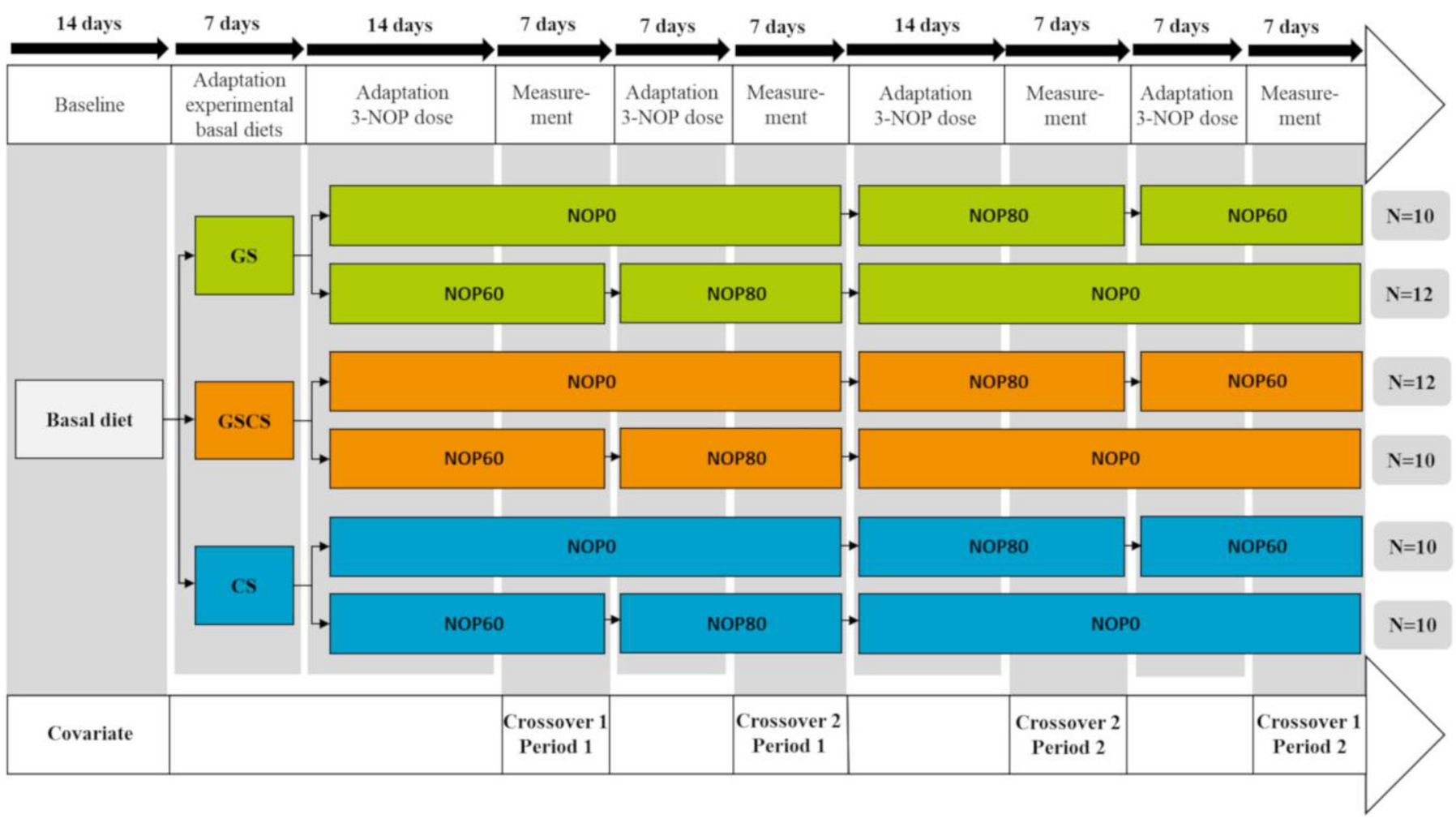

Figure 1. Scheme of the experimental setup. The experimental basal diets were a grass silage-based diet (GS; green), a grass silage- and corn silage-mixed diet (GSCS; orange), and a corn silage-based diet (CS; blue). These diets were supplemented with different dosages of 3-nitrooxypropanol (3-NOP); namely, 0, 60, or $80 \mathrm{mg}$ of 3-NOP/kg of DM (NOP0, NOP60, and NOP80, respectively). The first $14 \mathrm{~d}$ represents the covariate period in which baseline measurements took place. The experiment consisted of 2 crossovers, each with two 1-wk measurement periods. 
change in dietary composition (e.g., 3-NOP dosage), the Trioliet supplied different experimental diets to the FB and the cows did not have to switch to another FB. The FB were equipped with an automated identification system (monitor ID system based on transponders within the collar of the dairy cows) to enable access. The experimental diets were equally distributed over the FB across the barn to eliminate potential barn location effects. For each visit of a cow to a FB bin, the start and end time of the visit as well as the start and end weight of the FB bin were recorded. Visits without feed intake (i.e., a weight difference of $100 \mathrm{~g}$ or less recorded by the $\mathrm{FB}$ because a cow is passing by or pushing against the FB) were discarded. Weekly, the FB were calibrated by using a standard weight. The lying cubicles were covered with commercially available rubber mats and with wood shavings as bedding, and were cleaned daily. The dairy cows were exposed to light from 0500 to $2300 \mathrm{~h}$, had free access to clean drinking water, and were milked twice daily at around 0700 and $1700 \mathrm{~h}$ during the entire experiment. Cows were milked in a milking carrousel suited for 40 cows with automatic cow identification, milk recording, and milk cluster removal (AutoRotor PerFormer, Gea Farm Technologies). The dairy cows received no concentrate feeding during milking.

\section{Sample Collection and Measurements}

Samples of grass silage, corn silage, concentrates, GreenFeed bait, and premixes were taken once weekly and stored at $-20^{\circ} \mathrm{C}$ pending analysis. Once weekly, during 1 morning and 1 evening milking event, a milk sample $(10 \mathrm{~mL})$ was collected in a tube containing sodium azide $(5 \mu \mathrm{L})$ for preservation, stored no longer than $1 \mathrm{~d}$ at $4^{\circ} \mathrm{C}$, and analyzed for fat, protein, lactose, and urea content. A weighted average daily milk composition was calculated from milk composition and milk yield of both milking events. An additional milk sample $(100 \mathrm{~mL})$ was collected at a morning milking event of a measurement period and stored at $-20^{\circ} \mathrm{C}$ pending milk fatty acid (MFA) composition. The BW of each cow (identified via a monitor ID system) was recorded twice daily during the entire study. Cows were weighed as they exited the milking carrousel using a Gea weighing scale (Gea Farm Technologies).

\section{Gas Emissions}

Emissions of $\mathrm{CH}_{4}, \mathrm{H}_{2}$, and $\mathrm{CO}_{2}$ were measured on an individual animal level for the duration of the trial by using the GreenFeed system (C-Lock Inc.; Zimmerman et al., 2011). The GreenFeed system measures airflow as well as $\mathrm{CH}_{4}, \mathrm{H}_{2}$, and $\mathrm{CO}_{2}$ concentrations in exhaust air. Each GreenFeed unit was equipped with a head position sensor, and gas emission data were rejected when the head position criteria were not met. Unlike the FB to which the cows were specifically assigned, each GreenFeed unit could be visited by any cow. Each individual cow could visit the GreenFeed units every $2 \mathrm{~h}$ (with a maximum of 12 times/d), and data collection was dependent on the cows' voluntary visits to the GreenFeed units. The number of visits to the GreenFeed units resulting in reliable $\mathrm{CH}_{4}, \mathrm{H}_{2}$, and $\mathrm{CO}_{2}$ measurements was $44 \pm 15.1$ (mean $\pm \mathrm{SD}$ ) per cow per week, and hence, no cow was excluded from the data set because of insufficient number of visits to the GreenFeed units (i.e., minimum of 20 measurements; Manafiazer et al., 2017). A sweet, palatable concentrate was offered as bait (Table 1) at the GreenFeed units for enticement and to encourage the cow to maintain a suitable head position for accurate measurements. This GreenFeed bait was provided from a hopper above the GreenFeed hood by using a computer controlled rotating cup dispenser, with a maximum of 8 so-called cup drops per visit, 1 cup drop per $30 \mathrm{~s}$, and $35.7 \pm 2.22 \mathrm{~g}$ of feed per cup drop.

The emissions of $\mathrm{CH}_{4}, \mathrm{H}_{2}$, and $\mathrm{CO}_{2}$ were calculated by subtracting the recorded background gas concentration from the gas concentrations recorded during the animal's time in the GreenFeed. This difference in concentration was subsequently multiplied by the airflow to come to an emission rate in $\mathrm{g} / \mathrm{d}$, using the ideal gas law and correcting for temperature and pressure. The GreenFeed units measure $\mathrm{CH}_{4}, \mathrm{H}_{2}$, and $\mathrm{CO}_{2}$ gas concentrations using a nondispersive near-infrared analyzer (NDIR). The NDIR requires calibration using an air mixture to zero the analyzer, and then using a known certified gas concentration to adjust the span of the NDIR. Hence, the NDIR was calibrated every third day by using a zero-baseline gas $\left(20 \% \mathrm{O}_{2}\right.$ and $80 \% \mathrm{~N}_{2}$; Linde Gas Benelux B.V.) and a span gas mixture of $\mathrm{N}_{2}$ containing $10 \mathrm{ppm} \mathrm{H}_{2}, 1,000 \mathrm{ppm} \mathrm{CH}_{4}, 1 \% \mathrm{CO}_{2}$, and $21 \% \mathrm{O}_{2}$ (Linde Gas Benelux B.V.). This calibration was used to remove signal drift in the NDIR analyzer over time (managed by C-Lock Inc.), which was found to be negligible. To check the recovery of expired gases, a known amount of $\mathrm{CO}_{2}$ gas was released every month in the GreenFeed units near where the animal's nose would be when consuming the bait during a GreenFeed visit. The average recovery of $\mathrm{CO}_{2}$ was $99.2 \%$ (for individual GreenFeed units between 94.7 and 102.7\%). Based on the recovery tests performed, the flow coefficient was adjusted (managed C-Lock Inc.). The procedure followed for the calibration and recovery test was carried out according to Hristov et al. (2015b). 
A detailed description of how $\mathrm{CH}_{4}$ and $\mathrm{H}_{2}$ production (mass per unit of time) is measured by the GreenFeed system is provided by Hammond et al. (2015). Data from the GreenFeed units were available every $24 \mathrm{~h}$ by using communication through a web-based data management system provided by C-Lock Inc. The final data management was performed by C-Lock Inc. and we subsequently performed statistical analyses on the validated data set.

\section{Chemical Analysis}

At the end of the experiment, all feed samples were thawed at room temperature, freeze-dried until constant weight, and ground to pass a $1-\mathrm{mm}$ screen by using a cross beater mill for both silages (Peppink 100AN) and an ultracentrifugal mill for the GreenFeed bait, concentrates and premix samples (Retsch ZM200, Retsch $\mathrm{GmbH}$ ). The samples were subsequently analyzed by using wet chemistry for DM, ash, N, starch (except for grass silage), reducing sugars (i.e., all carbohydrates with reducing properties and soluble in $40 \%$ ethanol; except for corn silage), crude fat, NDF, ADF, and ADL as described by Abrahamse et al. (2008a). Bomb calorimetry (ISO 9831; International Organization for Standardization, 1998) was used to determine gross energy. Crude protein was calculated as $\mathrm{N} \times 6.25$, where $\mathrm{N}$ was determined using the Kjeldahl method with $\mathrm{CuSO}_{4}$ as catalyst (ISO 5983; International Organization for Standardization, 2005). The N concentrations in both forages were determined in fresh material according to Klop et al. (2016). Milk samples were analyzed for fat, protein, lactose, and urea content by mid-infrared spectroscopy (ISO 9622; International Organization for Standardization, 2013; Qlip B.V.). Fat- and proteincorrected milk yield (FPCM) was calculated according to the equation FPCM $(\mathrm{kg} / \mathrm{d})=(0.337+0.116 \times$ fat $\%$ $+0.06 \times$ protein $\%) \times$ milk yield $(\mathrm{kg} / \mathrm{d})(\mathrm{CVB}, 2018)$. Energy-corrected milk was calculated according to the equation $\operatorname{ECM}(\mathrm{kg} / \mathrm{d})=$ [milk yield $(\mathrm{kg} / \mathrm{d}) \times 0.327$ ] $+[$ fat yield $(\mathrm{kg} / \mathrm{d}) \times 12.95]+[$ protein yield $(\mathrm{kg} / \mathrm{d}) \times$ 7.25] (Tyrrell and Reid, 1965). The MFA composition was determined using GC (Thermo Electron Corporation) by Qlip (Qlip B.V.) with a split/splitless injector and $\mathrm{H}_{2}$ as carrier gas as described by van Gastelen et al. (2015). Samples of the experimental diets were collected 4 times during the study (representing each measurement period), frozen at $-20^{\circ} \mathrm{C}$ and at the end of the study transported to DSM Nutritional Products (Kaiseraugst, Switzerland) on dry ice for analysis of 3-NOP content, as described by van Gastelen et al. (2020).

\section{Statistical Analysis}

The final data set included 63 dairy cows. Due to persistent stealing behavior by 1 cow (i.e., stealing on average $9 \%$ of her daily DMI from FB other than from the FB to which the cow was assigned) throughout the trial despite presence of measures that prevent such behavior, this cow had to be excluded from the data set.

All parameters related to feed intake, lactation performance, and gaseous exchange were averaged per cow per period (i.e., covariate period and 4 measurement periods). Data were subsequently split into 2 data sets: (1) crossover with 0 and $60 \mathrm{mg}$ of $3-\mathrm{NOP} / \mathrm{kg}$ of $\mathrm{DM}$, consisting of measurement period 1 and 4 (including the covariate period as baseline measurement), (2) crossover with 0 and $80 \mathrm{mg}$ of $3-\mathrm{NOP} / \mathrm{kg}$ of $\mathrm{DM}$, consisting of measurement period 2 and 3 (including the covariate period as well as baseline measurement). Because it was possible to mix only 2 doses of 3 -NOP in the barn at any time point (i.e., 6 different diets), NOP60 and NOP80 were never fed simultaneously. Hence, statistical comparisons were performed for each 3-NOP dose (NOP60 and NOP80) versus NOP0 only.

Per crossover, data were subjected to ANOVA in a crossover with a 2 period $\times 2$ treatment design by using the MIXED procedure in SAS (edition 9.4, SAS Institute Inc.). The BD (GS, GSCS, and CS), the 3 -NOP dose $(0$ and $60 \mathrm{mg} / \mathrm{kg}$ of DM for the first crossover and 0 and $80 \mathrm{mg} / \mathrm{kg}$ of $\mathrm{DM}$ for the second crossover; NOP), the $\mathrm{BD} \times 3$-NOP dose interaction, treatment sequence (i.e., order in which the 3-NOP dosages were supplemented within crossover), period, as well as the baseline measurement from the covariate period were considered fixed effects. The model included block and cow as random factors. The covariance structure variance components provided the best fit with the lowest overall Akaike's information criterion values. The Kenward-Roger option was used to estimate the denominator degrees of freedom. Multiple comparisons among treatment means were made by using the Tukey-Kramer method when an effect of $\mathrm{BD}$ or $\mathrm{BD} \times 3$-NOP dose interaction was detected at $P$ $\leq 0.05$. Additionally, within each crossover, we calculated the decrease in $\mathrm{CH}_{4}$ and increase in $\mathrm{H}_{2}$ emissions for NOP60 or NOP80 relative to NOP0 for each cow. These data were subsequently subjected to ANOVA using the MIXED procedure in SAS, where the BD and treatment sequence were considered fixed effects. The model included block and cow as random factors. All results are reported as least squares means with significance of effects declared at $P \leq 0.05$ and trends at $0.05<P \leq 0.10$. 


\section{RESULTS}

The average 3-NOP recovery of the experimental diets in the crossover with $63 \mathrm{mg}$ of $3-\mathrm{NOP} / \mathrm{kg}$ of DM as target, was $104 \pm 8.4 \%$ (i.e., $95 \%$ for GS, $110 \%$ for GSCS, and $108 \%$ for CS). When corrected for the DMI of the GreenFeed bait (not supplemented with $3-\mathrm{NOP}$ ), the overall inclusion levels of 3-NOP for total daily DMI were on average $62 \mathrm{mg}$ of $3-\mathrm{NOP} / \mathrm{kg}$ of DM; namely 56,66 , and $65 \mathrm{mg} / \mathrm{kg}$ of DM for GS_NOP60, GSCS_NOP60, and CS_NOP60, respectively. The average 3-NOP recovery of the experimental diets in the crossover with $84 \mathrm{mg}$ of $3-\mathrm{NOP} / \mathrm{kg}$ of DM as target, was $101 \pm 7.3 \%$ (96\% for GS, $97 \%$ for GSCS, and $109 \%$ for CS). When corrected for the DMI of the GreenFeed bait (not supplemented with 3-NOP), the overall inclusion levels of 3-NOP for total daily DM intake were on average $80 \mathrm{mg}$ of 3 -NOP $/ \mathrm{kg}$ of DM; namely 75,78 , and $87 \mathrm{mg} / \mathrm{kg}$ of DM for GS_NOP80, GSCS_NOP80, and CS_NOP80, respectively.

\section{Gas Emissions}

In the crossover with $60 \mathrm{mg}$ of $3-\mathrm{NOP} / \mathrm{kg}$ of $\mathrm{DM}$, $\mathrm{CH}_{4}$ production $(\mathrm{g} / \mathrm{d})$ was affected $(P=0.01)$ by a $\mathrm{BD}$ $\times$ NOP interaction and $\mathrm{CH}_{4}$ yield $(\mathrm{g} / \mathrm{kg}$ DMI $)$ tended to be affected $(P=0.07)$ by a $\mathrm{BD} \times \mathrm{NOP}$ interaction (Table 3). In the crossover with $80 \mathrm{mg}$ of $3-\mathrm{NOP} / \mathrm{kg}$ of DM, all measures of $\mathrm{CH}_{4}$ emission were affected $(P \leq$ 0.05 ; Table 4$)$ by a $\mathrm{BD} \times \mathrm{NOP}$ interaction. The $\mathrm{BD}$ $\times$ NOP interactions are the result of the difference in the mitigating effect of $3-\mathrm{NOP}$ with the different BD. Figure 2 shows the reduction (\% relative to NOP0) of $\mathrm{CH}_{4}$ production, $\mathrm{CH}_{4}$ yield, and $\mathrm{CH}_{4}$ intensity $(\mathrm{g} / \mathrm{kg}$ FPCM) with the 3 different BD for both NOP60 and NOP80. The mitigating effect of NOP60 was smaller $(P<0.01)$ when supplemented to GS $(-28.2,-26.2$, and $-26.5 \%$ for $\mathrm{CH}_{4}$ production, yield, and intensity, respectively) compared with both GSCS $(-37.0,-35.1$, and $-35.5 \%$ for $\mathrm{CH}_{4}$ production, yield, and intensity, respectively) and $\mathrm{CS}\left(-38.0,-34.8\right.$, and $-38.2 \% \mathrm{CH}_{4}$ production, yield, and intensity, respectively), with no difference between the latter $2 \mathrm{BD}$ (Figure 2). Also, the mitigating effect of NOP80 was smaller $(P<0.01)$ when supplemented to GS $(-31.4,-28.4$, and $-27.9 \%$ for $\mathrm{CH}_{4}$ production, yield, and intensity, respectively) compared with both GSCS $(-42.0,-37.9$, and $-39.1 \%$ for $\mathrm{CH}_{4}$ production, yield, and intensity, respectively) and CS $\left(-45.1,-41.6\right.$, and $-44.3 \% \mathrm{CH}_{4}$ production, yield, and intensity, respectively), with no difference between the latter $2 \mathrm{BD}$ (Figure 2). In the crossover with 0 and $60 \mathrm{mg}$ of $3-\mathrm{NOP} / \mathrm{kg}$ of $\mathrm{DM}, \mathrm{CH}_{4}$ yield and both measures of $\mathrm{CH}_{4}$ intensity were affected by BD $(P$ $<0.01)$ as well as 3 -NOP dose $(P<0.01)$. All 3 measures of $\mathrm{CH}_{4}$ emissions decreased from GS to GSCS to CS, and were smaller for NOP60 compared with NOP0.

In the crossover with $60 \mathrm{mg}$ of $3-\mathrm{NOP} / \mathrm{kg}$ of DM, both $\mathrm{H}_{2}$ production $(\mathrm{g} / \mathrm{d})$ and $\mathrm{H}_{2}$ yield $(\mathrm{g} / \mathrm{kg} \mathrm{DMI})$ were affected $(P \leq 0.02)$, and both measures of $\mathrm{H}_{2}$ intensity $(\mathrm{g} / \mathrm{kg}$ ECM and $\mathrm{g} / \mathrm{kg}$ FPCM) tended to be affected $(P$

Table 3. Methane and hydrogen emission of lactating dairy cows fed different basal diets (BD; where GS = grass silage-based diet, GSCS = grass silage- and corn silage-mixed diet, $\mathrm{CS}=$ corn silage-based diet) supplemented with 0 or $60 \mathrm{mg}$ of 3-nitrooxypropanol/kg of DM (NOP)

\begin{tabular}{|c|c|c|c|c|c|c|c|c|c|}
\hline \multirow[b]{2}{*}{ Item } & \multicolumn{3}{|c|}{$\mathrm{BD}$} & \multicolumn{2}{|c|}{$\begin{array}{c}\text { 3-NOP dose } \\
\text { (mg/kg DM) }\end{array}$} & \multirow[b]{2}{*}{ SEM } & \multicolumn{3}{|c|}{$P$-value } \\
\hline & GS & GSCS & CS & 0 & 60 & & $\mathrm{BD}$ & $\mathrm{NOP}$ & $\mathrm{BD} \times \mathrm{NOP}$ \\
\hline Production $(\mathrm{g} / \mathrm{d})$ & 14,527 & 14,863 & 14,596 & 14,647 & 14,677 & 112.8 & 0.14 & 0.79 & 0.37 \\
\hline Yield $(\mathrm{g} / \mathrm{kg}$ of DMI) & $684^{\mathrm{a}}$ & $667^{\mathrm{a}}$ & $623^{\mathrm{b}}$ & 649 & 667 & 9.8 & $<0.01$ & $<0.01$ & 0.79 \\
\hline \multicolumn{10}{|l|}{$\mathrm{CH}_{4}$ emissions } \\
\hline Intensity (g/kg of ECM) & $12.0^{\mathrm{a}}$ & $11.3^{\mathrm{b}}$ & $10.4^{\mathrm{c}}$ & 13.5 & 9.0 & 0.21 & $<0.01$ & $<0.01$ & 0.13 \\
\hline Intensity $(\mathrm{g} / \mathrm{kg}$ of $\mathrm{FPCM})$ & $13.1^{\mathrm{a}}$ & $12.3^{\mathrm{b}}$ & $11.4^{\mathrm{c}}$ & 14.8 & 9.8 & 0.23 & $<0.01$ & $<0.01$ & 0.13 \\
\hline \multicolumn{10}{|l|}{$\mathrm{H}_{2}$ emissions } \\
\hline Production $(\mathrm{g} / \mathrm{d})^{2}$ & 5.08 & 5.49 & 5.22 & 2.31 & 8.22 & 0.186 & 0.32 & $<0.01$ & 0.01 \\
\hline Yield $(\mathrm{g} / \mathrm{kg} \text { of } \mathrm{DMI})^{3}$ & 0.237 & 0.252 & 0.224 & 0.104 & 0.372 & 0.0086 & 0.12 & $<0.01$ & 0.02 \\
\hline Intensity (g/kg of ECM) & $0.169^{\mathrm{ab}}$ & $0.174^{\mathrm{a}}$ & $0.147^{\mathrm{b}}$ & 0.072 & 0.254 & 0.0066 & 0.04 & $<0.01$ & 0.06 \\
\hline Intensity $(\mathrm{g} / \mathrm{kg}$ of $\mathrm{FPCM})$ & 0.182 & 0.191 & 0.164 & 0.079 & 0.278 & 0.0076 & 0.11 & $<0.01$ & 0.06 \\
\hline
\end{tabular}

${ }^{\mathrm{a}-\mathrm{c}}$ Values with a different superscript indicate a significant $(P<0.05)$ difference between the BD.

${ }^{1} \mathrm{BD} \times$ NOP interaction; GS NOP0 $=438^{\mathrm{v}}$, GS NOP60 $=311^{\mathrm{w}}$, GSCS NOP0 $=445^{\mathrm{v}}$, GSCS NOP60 $=279^{\mathrm{x}}$, CS NOP0 $=434^{\mathrm{v}}$, and CS NOP60 $=265^{\mathrm{x}}$. Different superscripts indicate a significant $(P<0.05)$ difference.

${ }^{2} \mathrm{BD} \times \mathrm{NOP}$ interaction; GS NOP0 $=2.57^{\mathrm{v}}$, GS NOP60 $=7.59^{\mathrm{w}}$, GSCS NOP0 $=2.45^{\mathrm{v}}$, GSCS NOP60 $=8.54^{\mathrm{x}}$, CS NOP0 $=1.91^{\mathrm{v}}$, and CS NOP60 $=8.53^{\mathrm{x}}$. Different superscripts indicate a significant $(P<0.05)$ difference.

${ }^{3} \mathrm{BD} \times \mathrm{NOP}$ interaction; GS NOP0 $=0.120^{\mathrm{v}}$, GS NOP60 $=0.354^{\mathrm{x}}$, GSCS NOP0 $=0.112^{\mathrm{vw}}$, GSCS NOP $60=0.393^{\mathrm{y}}, \mathrm{CS}$ NOP0 $=0.079^{\mathrm{w}}$, and CS NOP60 $=0.369^{\mathrm{xy}}$. Different superscripts indicate a significant $(P<0.05)$ difference. 
Table 4. Methane and hydrogen emission of lactating dairy cows fed different basal diets (BD; where GS = grass silage-based diet, GSCS $=$ grass silage- and corn silage-mixed diet, $\mathrm{CS}=$ corn silage-based diet) supplemented with 0 or $80 \mathrm{mg}$ of 3-nitrooxypropanol $/ \mathrm{kg}$ of $\mathrm{DM}$ (NOP)

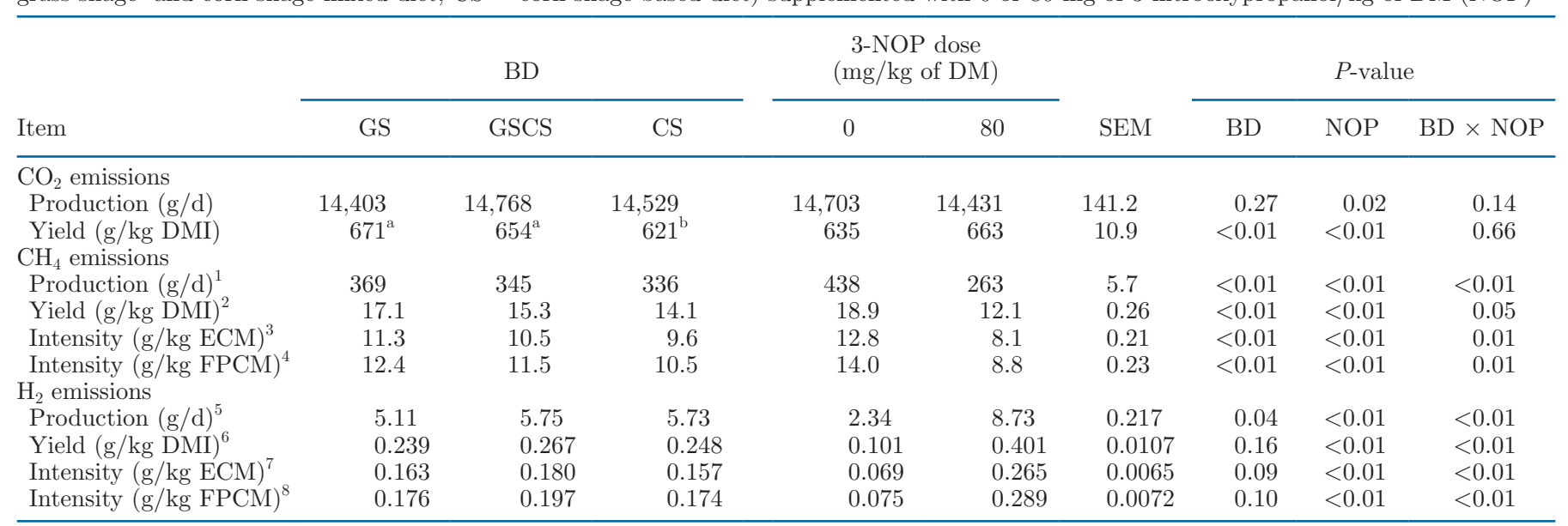

${ }^{\mathrm{a}, \mathrm{b}}$ Values with a different superscript indicate a significant $(P<0.05)$ difference between 0,40 , and $80 \%$ corn silage of the forage.

${ }^{1} \mathrm{BD} \times \mathrm{NOP}$ interaction; GS NOP0 $=439^{\mathrm{v}}$, GS NOP $80=298^{\mathrm{w}}$, GSCS NOP0 $=438^{\mathrm{v}}$, GSCS NOP $80=253^{\mathrm{x}}$, CS NOP0 $=436^{\mathrm{v}}$, and CS NOP 80 $=237^{\mathrm{x}}$. Different superscripts indicate a significant $(P<0.05)$ difference.

${ }^{2} \mathrm{BD} \times$ NOP interaction; GS NOP0 $=20.0^{\mathrm{u}}$, GS NOP $80=14.2^{\mathrm{v}}$, GSCS NOP0 $=18.9^{\mathrm{w}}$, GSCS NOP $80=11.8^{\mathrm{x}}$, CS NOP0 $=17.8^{\mathrm{y}}$, and CS NOP 80 $=10.4^{\mathrm{Z}}$. Different superscripts indicate a significant $(P<0.05)$ difference.

${ }^{3} \mathrm{BD} \times$ NOP interaction; GS NOP0 $=13.2^{\mathrm{v}}$, GS NOP $80=9.4^{\mathrm{x}}$, GSCS NOP0 $=13.0^{\mathrm{vw}}$, GSCS NOP $80=8.0^{\mathrm{y}}, \mathrm{CS}$ NOP0 $=12.3^{\mathrm{w}}$, and CS NOP 80 $=6.9^{z}$. Different superscripts indicate a significant $(P<0.05)$ difference.

${ }^{4} \mathrm{BD} \times \mathrm{NOP}$ interaction; GS NOP0 $=14.5^{\mathrm{v}}$, GS NOP $80=10.2^{\mathrm{x}}$, GSCS NOP0 $=14.2^{\mathrm{vw}}$, GSCS NOP $80=8.7^{\mathrm{y}}$, CS NOP0 $=13.4^{\mathrm{w}}$, and CS NOP 80 $=7.6^{z}$. Different superscripts indicate a significant $(P<0.05)$ difference.

${ }^{5} \mathrm{BD} \times \mathrm{NOP}$ interaction; GS NOP0 $=2.49^{\mathrm{v}}$, GS NOP $80=7.74^{\mathrm{w}}$, GSCS NOP0 $=2.33^{\mathrm{v}}$, GSCS NOP $80=9.17^{\mathrm{x}}$, CS NOP0 $=2.20^{\mathrm{v}}$, and CS NOP 80 $=9.27^{\mathrm{x}}$. Different superscripts indicate a significant $(P<0.05)$ difference.

${ }^{6} \mathrm{BD} \times \mathrm{NOP}$ interaction; GS NOP0 $=0.113^{\mathrm{v}}$, GS NOP $80=0.365^{\mathrm{w}}$, GSCS NOP0 $=0.103^{\mathrm{v}}$, GSCS NOP $80=0.431^{\mathrm{x}}$, CS NOP0 $=0.088^{\mathrm{v}}$, and CS NOP $80=0.407^{\mathrm{x}}$. Different superscripts indicate a significant $(P<0.05)$ difference.

${ }^{7} \mathrm{BD} \times \mathrm{NOP}$ interaction; GS NOP0 $=0.079^{\mathrm{v}}$, GS NOP $80=0.247^{\mathrm{w}}$, GSCS NOP0 $=0.071^{\mathrm{v}}$, GSCS NOP $80=0.288^{\mathrm{x}}$, CS NOP0 $=0.055^{\mathrm{v}}$, and CS NOP80 $=0.259^{\mathrm{w}}$. Different superscripts indicate a significant $(P<0.05)$ difference.

${ }^{8}$ BD $\times$ NOP interaction; GS NOP0 $=0.085^{\mathrm{v}}$, GS NOP $80=0.268^{\mathrm{w}}$, GSCS NOP0 $=0.078^{\mathrm{v}}$, GSCS NOP $80=0.315^{\mathrm{x}}, \mathrm{CS}$ NOP0 $=0.062^{\mathrm{v}}$, and CS NOP $80=0.285^{\mathrm{w}}$. Different superscripts indicate a significant $(P<0.05)$ difference.

$=0.06)$ by a $\mathrm{BD} \times \mathrm{NOP}$ interaction. In the crossover with $80 \mathrm{mg}$ of $3-\mathrm{NOP} / \mathrm{kg}$ of $\mathrm{DM}$, all measures of $\mathrm{H}_{2}$ emission were affected $(P \leq 0.01)$ by a $\mathrm{BD} \times \mathrm{NOP}$ interaction. The $\mathrm{BD} \times \mathrm{NOP}$ interactions are the result of the difference in the fold increase in $\mathrm{H}_{2}$ emissions in response to 3 -NOP with the different BD. Figure 3 shows the fold increase in $\mathrm{H}_{2}$ production (g/d), $\mathrm{H}_{2}$ yield (g/kg DMI), and $\mathrm{H}_{2}$ intensity $(\mathrm{g} / \mathrm{kg}$ FPCM) with the 3 BD for both NOP60 and NOP80. The fold increase in $\mathrm{H}_{2}$ emissions in response to NOP60 increased from GS (i.e., 3.10, 3.16, and 3.15 for $\mathrm{H}_{2}$ production, yield, and intensity, respectively) to GSCS (i.e., 3.71, 3.76, and 3.84 for $\mathrm{H}_{2}$ production, yield, and intensity, respectively) and further to CS (i.e., 4.48, 4.70, and 4.54 for $\mathrm{H}_{2}$ production, yield, and intensity, respectively). Similarly, the fold increase in $\mathrm{H}_{2}$ emissions in response to NOP80 increased from GS (i.e., 3.18, 3.30, and 3.35 for $\mathrm{H}_{2}$ production, yield, and intensity, respectively) to both GSCS (i.e., 4.10, 4.43, and 4.36 for $\mathrm{H}_{2}$ production, yield, and intensity, respectively) and CS (i.e., 4.63, 4.96, and 4.73 for $\mathrm{H}_{2}$ production, yield, and intensity, respectively), with no difference between the latter 2
BD. In the crossover with 0 and $60 \mathrm{mg}$ of $3-\mathrm{NOP} / \mathrm{kg}$ of DM, $\mathrm{H}_{2}$ intensity ( $\mathrm{g} / \mathrm{kg}$ FPCM) was affected by the $\mathrm{BD}$, being smaller $(P=0.04)$ for CS compared with GSCS. Both measures of $\mathrm{H}_{2}$ intensity were larger $(P<$ 0.01) for NOP60 compared with NOP0.

No $\mathrm{BD} \times \mathrm{NOP}$ interactions were observed for $\mathrm{CO}_{2}$ emissions. In both crossovers, BD did not affect production of $\mathrm{CO}_{2}$, but $\mathrm{CO}_{2}$ yield was smaller $(P<0.01)$ for CS compared with GS. In the crossover with 60 $\mathrm{mg}$ of $3-\mathrm{NOP} / \mathrm{kg}$ of DM, 3-NOP supplementation only resulted in a greater $(P<0.01) \mathrm{CO}_{2}$ yield, whereas in the crossover with $80 \mathrm{mg}$ of $3-\mathrm{NOP} / \mathrm{kg}$ of $\mathrm{DM}, 3-\mathrm{NOP}$ supplementation decreased $(P=0.02) \mathrm{CO}_{2}$ production and increased $(P<0.01) \mathrm{CO}_{2}$ yield.

\section{Feed Intake}

No BD $\times$ NOP interactions were observed for any of the feed intake characteristics (Tables 5 and 6 ). In the crossover with $60 \mathrm{mg}$ of $3-\mathrm{NOP} / \mathrm{kg}$ of $\mathrm{DM}$, the number of visits to the GreenFeed was larger $(P<0.01)$ for GS compared with both GSCS and CS, with no dif- 

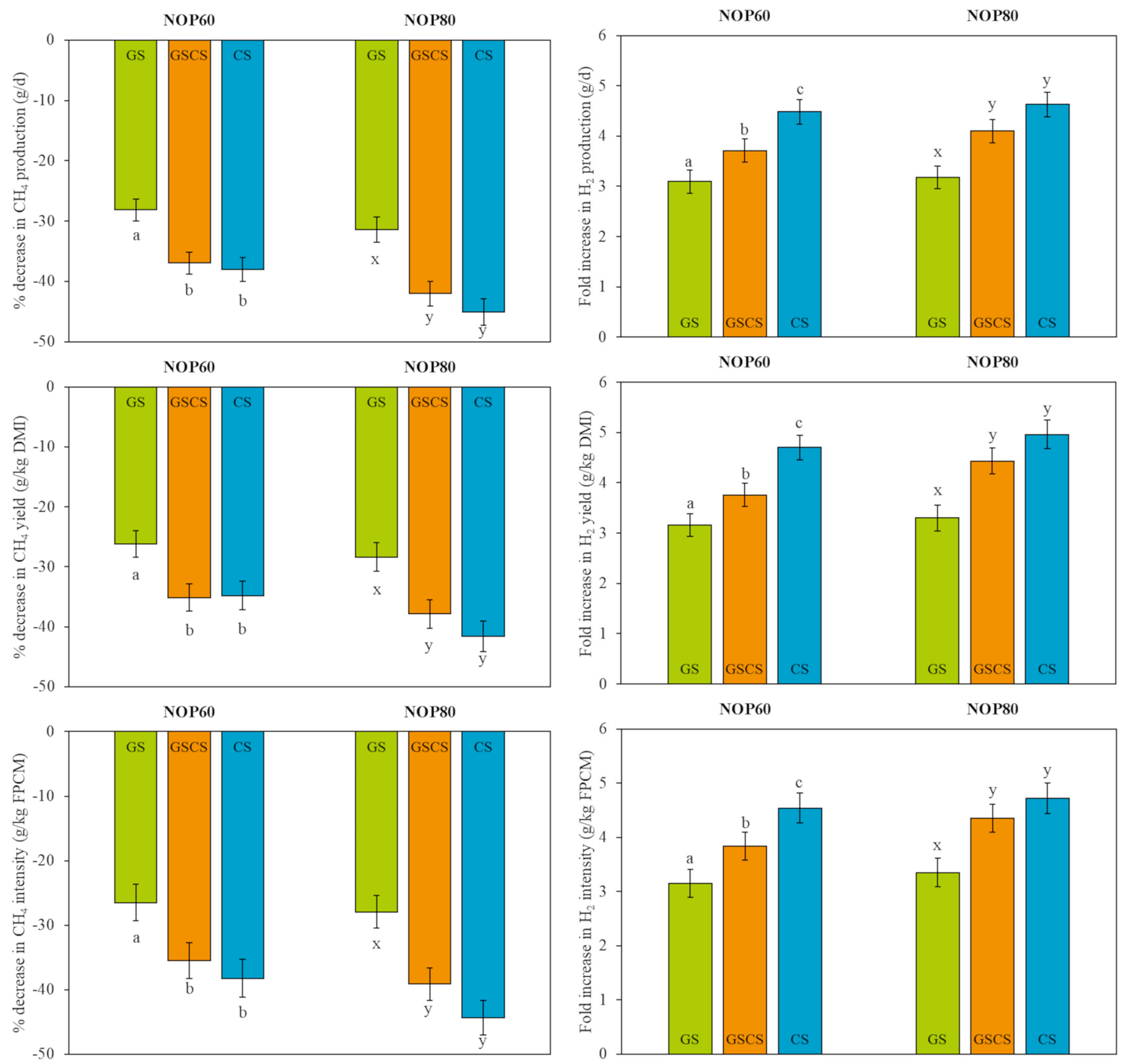

Figure 2. The decrease (\%) in $\mathrm{CH}_{4}$ production (g/d; upper panel), $\mathrm{CH}_{4}$ yield ( $\mathrm{g} / \mathrm{kg}$ of DMI; middle panel), and $\mathrm{CH}_{4}$ intensity $[\mathrm{g} / \mathrm{kg}$ of fatand protein-corrected milk (FPCM); lower panel] of dairy cows treated with $60 \mathrm{mg}$ (NOP60) or with $80 \mathrm{mg}$ (NOP80) of 3-nitrooxypropanol/ $\mathrm{kg}$ of DM compared with a placebo for 3 basal diets: a grass silagebased diet (GS), a grass silage- and corn silage-mixed diet (GSCS), and a corn silage-based diet (CS). Bars with no common letters differ within $\operatorname{NOP} 60(\mathrm{a}, \mathrm{b})$ and within $\operatorname{NOP} 80(\mathrm{x}, \mathrm{y})(P<0.05)$. Data are treatment $\mathrm{LSM} \pm \mathrm{SD}$.

ference between the latter 2 BD (Table 5). The DMI of the GreenFeed bait decreased $(P<0.01)$ from GS to GSCS, with CS in between. The latter pattern was

Figure 3. The fold increase in $\mathrm{H}_{2}$ production (g/d; upper panel), $\mathrm{H}_{2}$ yield (g/kg DMI; middle panel), and $\mathrm{H}_{2}$ intensity [ $(\mathrm{g} / \mathrm{kg}$ fat- and protein-corrected milk (FPCM); lower panel] of dairy cows treated with $60 \mathrm{mg}$ of 3-nitrooxypropanol $/ \mathrm{kg}$ of DM (NOP60) and with $80 \mathrm{mg}$ of 3-nitrooxypropanol/kg of DM (NOP80) compared with a placebo for 3 different basal diets: a grass silage-based diet (GS), a grass silageand corn silage-mixed diet (GSCS), and a corn silage-based diet (CS). Bars with no common letters differ within NOP60 (a-c) and within NOP80 $(\mathrm{x}, \mathrm{y})(P<0.05)$. Data are treatment LSM \pm SD.

also observed for the number of GreenFeed visits in the crossover with $80 \mathrm{mg}$ of $3-\mathrm{NOP} / \mathrm{kg}$ of DM (Table 6 ), where the number of GreenFeed visits decreased $(P<$ 
Table 5. Feed intake of lactating dairy cows fed different basal diets (BD; where GS = grass silage-based diet, GSCS = grass silage- and corn silage-mixed diet, $\mathrm{CS}=$ corn silage-based diet) supplemented with 0 or $60 \mathrm{mg}$ of 3-nitrooxypropanol $/ \mathrm{kg}$ of $\mathrm{DM}$ (NOP)

\begin{tabular}{|c|c|c|c|c|c|c|c|c|c|}
\hline \multirow[b]{2}{*}{ Item } & \multicolumn{3}{|c|}{$\mathrm{BD}$} & \multicolumn{2}{|c|}{$\begin{array}{l}\text { 3-NOP dose } \\
(\mathrm{mg} / \mathrm{kg} \text { of } \mathrm{DM})\end{array}$} & \multirow[t]{2}{*}{ SEM } & \multicolumn{3}{|c|}{$P$-value } \\
\hline & GS & GSCS & CS & 0 & 60 & & $\mathrm{BD}$ & NOP & $\mathrm{BD} \times \mathrm{NOP}$ \\
\hline Visits to the GreenFeeds (number/d) & $6.3^{\mathrm{a}}$ & $4.8^{\mathrm{b}}$ & $5.4^{\mathrm{b}}$ & 5.5 & 5.6 & 0.22 & $<0.01$ & 0.21 & 0.21 \\
\hline DMI GreenFeed bait $(\mathrm{kg} / \mathrm{d})$ & $1.32^{\mathrm{a}}$ & $1.01^{\mathrm{c}}$ & $1.16^{\mathrm{b}}$ & 1.15 & 1.17 & 0.038 & $<0.01$ & 0.40 & 0.27 \\
\hline DMI partially mixed ration $(\mathrm{kg} / \mathrm{d})$ & $20.0^{\mathrm{a}}$ & $21.2^{\mathrm{b}}$ & $22.4^{\mathrm{c}}$ & 21.5 & 20.9 & 0.20 & $<0.01$ & $<0.01$ & 0.32 \\
\hline DMI total $(\mathrm{kg} / \mathrm{d})$ & $21.3^{\mathrm{a}}$ & $22.2^{\mathrm{b}}$ & $23.6^{\mathrm{c}}$ & 22.7 & 22.1 & 0.20 & $<0.01$ & $<0.01$ & 0.32 \\
\hline $\begin{array}{l}\text { Feed efficiency }\left(\mathrm{kg} \text { of } \mathrm{FPCM}^{2} /\right. \\
\mathrm{kg} \text { of DMI total) }\end{array}$ & 1.36 & 1.35 & 1.32 & 1.34 & 1.35 & 0.019 & 0.40 & 0.50 & 0.39 \\
\hline
\end{tabular}

${ }^{\mathrm{a}-\mathrm{c}}$ Values with a different superscript indicate a significant $(P<0.05)$ difference between the BD.

${ }^{1} \mathrm{ECM}=[$ milk yield $(\mathrm{kg} / \mathrm{d}) \times 0.327]+[$ fat yield $(\mathrm{kg} / \mathrm{d}) \times 12.95]+[$ protein yield $(\mathrm{kg} / \mathrm{d}) \times 7.25]($ Tyrrell and Reid, 1965).

${ }^{2}$ Fat- and protein-corrected milk $=[0.337+0.116 \times$ fat $(\mathrm{g} / 100 \mathrm{~g})+0.06 \times$ protein $(\mathrm{g} / 100 \mathrm{~g})] \times$ milk yield $(\mathrm{kg} / \mathrm{d})(\mathrm{CVB}, 2018)$.

0.01) from GS to GSCS, with CS in between. The DMI of the GreenFeed bait in the crossover with $80 \mathrm{mg}$ of $3-\mathrm{NOP} / \mathrm{kg}$ of $\mathrm{DM}$ was smaller $(P<0.01)$ for GSCS compared with both GS and CS. In both crossovers, the DMI of the partially mixed ration as well as total DMI increased $(P<0.01)$ from GS to GSCS and further to CS. Feed efficiency was not affected by BD.

The DMI of the partially mixed ration as well as total DMI were smaller $(P<0.01)$ for NOP60 compared with NOP0 (Table 5), as well as for NOP80 compared with NOP0 (Table 6). Number of visits to the GreenFeed, DMI of GreenFeed bait, and feed efficiency were not affected by NOP.

\section{Body Weight and Lactation Performance}

Milk urea content tended $(P=0.06$; Table 7$)$ to be affected by a $\mathrm{BD} \times \mathrm{NOP}$ interaction in the crossover with $60 \mathrm{mg}$ of $3-\mathrm{NOP} / \mathrm{kg}$ of DM. The sum of the SFA, UFA, PUFA, and trans MFA (all relative to total amount of fatty acids) were affected $(P \leq 0.03)$, and the sum of MUFA tended to be affected $(P=0.07)$ by a $\mathrm{BD} \times \mathrm{NOP}$ interaction, but only in the crossover with $80 \mathrm{mg}$ of $3-\mathrm{NOP} / \mathrm{kg}$ of DM (Table 8 ). The sum of SFA increased $(P=0.02)$ with NOP80 compared with NOP0, but only with GS. The sum of UFA decreased $(P=0.03)$ with NOP80 compared with NOP0 for both GS and GSCS, but not for CS. The sum of PUFA and of all trans MFA increased $(P<0.01)$ with NOP80 compared with NOP0, but only with CS.

In both crossovers, milk yield $(\mathrm{kg} / \mathrm{d})$ was larger $(P<$ 0.01) for CS compared with both GS and GSCS, with no difference between the latter $2 \mathrm{BD}$. The content of the major milk components was not affected by BD in the crossover with $60 \mathrm{mg}$ of $3-\mathrm{NOP} / \mathrm{kg}$ of $\mathrm{DM}$, but in the crossover with $80 \mathrm{mg}$ of $3-\mathrm{NOP} / \mathrm{kg}$ of $\mathrm{DM}$, milk fat content was greater $(P<0.01)$ for GS compared with both GSCS and CS (with no difference between the latter $2 \mathrm{BD}$ ). The increase in milk yield in combination with an unaffected milk composition resulted, in the

Table 6. Feed intake of lactating dairy cows fed different basal diets (BD; where GS = grass silage-based diet, GSCS = grass silage- and corn silage-mixed diet, $\mathrm{CS}=$ corn silage-based diet) supplemented with 0 or $80 \mathrm{mg}$ of 3-nitrooxypropanol $(\mathrm{NOP}) / \mathrm{kg}$ of DM

\begin{tabular}{|c|c|c|c|c|c|c|c|c|c|}
\hline \multirow[b]{2}{*}{ Item } & \multicolumn{3}{|c|}{$\mathrm{BD}$} & \multicolumn{2}{|c|}{$\begin{array}{l}\text { 3-NOP dose } \\
(\mathrm{mg} / \mathrm{kg} \text { of } \mathrm{DM})\end{array}$} & \multirow[b]{2}{*}{ SEM } & \multicolumn{3}{|c|}{$P$-value } \\
\hline & GS & GSCS & CS & 0 & 80 & & $\mathrm{BD}$ & NOP & $\mathrm{BD} \times \mathrm{NOP}$ \\
\hline DMI GreenFeed bait $(\mathrm{kg} / \mathrm{d})$ & $1.35^{\mathrm{a}}$ & $1.05^{\mathrm{b}}$ & $1.23^{\mathrm{a}}$ & 1.19 & 1.23 & 0.037 & $<0.01$ & 0.15 & 0.90 \\
\hline DMI partially mixed ration $(\mathrm{kg} / \mathrm{d})$ & $20.2^{\mathrm{a}}$ & $21.5^{\mathrm{b}}$ & $22.4^{\mathrm{c}}$ & 22.0 & 20.7 & 0.26 & $<0.01$ & $<0.01$ & 0.20 \\
\hline DMI total $(\mathrm{kg} / \mathrm{d})$ & $21.5^{\mathrm{a}}$ & $22.5^{\mathrm{b}}$ & $23.6^{\mathrm{c}}$ & 23.2 & 21.9 & 0.25 & $<0.01$ & $<0.01$ & 0.18 \\
\hline $\begin{array}{l}\text { Feed efficiency }\left(\mathrm{kg} \text { of } \mathrm{FPCM}^{2} /\right. \\
\mathrm{kg} \text { of DMI total) }\end{array}$ & 1.40 & 1.37 & 1.37 & 1.37 & 1.39 & 0.020 & 0.55 & 0.17 & 0.45 \\
\hline
\end{tabular}

\footnotetext{
${ }^{\mathrm{a}-\mathrm{c}}$ Values with a different superscript indicate a significant $(P<0.05)$ difference between the BD.

${ }^{1} \mathrm{ECM}=[$ milk yield $(\mathrm{kg} / \mathrm{d}) \times 0.327]+[$ fat yield $(\mathrm{kg} / \mathrm{d}) \times 12.95]+[$ protein yield $(\mathrm{kg} / \mathrm{d}) \times 7.25]($ Tyrrell and Reid, 1965).

${ }^{2}$ Fat- and protein-corrected milk $=[0.337+0.116 \times$ fat $(\mathrm{g} / 100 \mathrm{~g})+0.06 \times$ protein $(\mathrm{g} / 100 \mathrm{~g})] \times$ milk yield $(\mathrm{kg} / \mathrm{d})(\mathrm{CVB}, 2018)$.
} 
crossover with $60 \mathrm{mg}$ of $3-\mathrm{NOP} / \mathrm{kg}$ of $\mathrm{DM}$, in greater $(P \leq 0.04)$ yields of all major milk components, ECM, and FPCM for CS compared with GS. The same was observed for the crossover with $80 \mathrm{mg}$ of $3-\mathrm{NOP} / \mathrm{kg}$ of $\mathrm{DM}(P \leq 0.02)$, with the exception for fat yield (tendency only; $P=0.08$ ) because of the increased milk yield in combination with decreased milk fat content. The sum of all trans MFA was larger $(P<0.01)$ for CS compared with GS, but only in the crossover with 60 $\mathrm{mg}$ of $3-\mathrm{NOP} / \mathrm{kg}$ of DM.

None of the lactation characteristics were affected by 3 -NOP in the crossover with $60 \mathrm{mg}$ of $3-\mathrm{NOP} / \mathrm{kg}$ of DM, with the exception of MFA. The sum of odd- and branched-chain fatty acids (OBCFA), SFA, and trans MFA were larger $(P<0.01)$ for NOP60 compared with NOP0, whereas both the sum of UFA and MUFA were smaller $(P<0.01)$ for NOP60 compared with NOP0. In the crossover with $80 \mathrm{mg}$ of $3-\mathrm{NOP} / \mathrm{kg}$ of $\mathrm{DM}$, both milk fat content and milk protein content tended to be greater $(P \leq 0.07)$ and milk urea content was greater $(P<0.01)$ for NOP80 compared with NOP0. Body weight, milk production, daily yield of the major milk components, ECM, and FPCM were smaller $(P<0.01)$ for NOP80 compared with NOP0. The sum of OBCFA was larger $(P<0.01)$ whereas the sum of MUFA was smaller $(P<0.01)$ for NOP80 compared with NOP0. The effect of BD and NOP on the individual MFA constituting the aggregated groups of MFA are presented in Supplemental Tables S1 and S2 (https://doi.org/10 .17632/98ybrw5zjw.1; van Gastelen, 2022b).

\section{DISCUSSION}

Differences in the BD composition in the present study were achieved by replacing grass silage with corn silage and associated types of concentrates. We are aware that by doing this, the change in forage composition is confounded by a change in concentrate composition. However, this is a practical and relevant approach, normally applied in the dairy sector, and the size and impact of the confounding effect must have been relatively small as the diet was composed of $30 \%$ concentrates on a DM basis only and changes in dietary composition are to be attributed mainly to change in forage type.

Inhibition of methanogenesis by 3 -NOP is considered to be directly and rapidly reversible both in vitro (Duin et al., 2016) and in vivo (Reynolds et al., 2014; Muetzel et al., 2019). Even though several studies (e.g., Lopes et al., 2016; Haisan et al., 2016; Van Wesemael et al.,

Table 7. Body weight and lactation characteristics of lactating dairy cows fed different basal diets (BD; where GS = grass silage-based diet, GSCS = grass silage- and corn silage-mixed diet, CS = corn silage-based diet) supplemented with 0 or $60 \mathrm{mg}$ of 3-nitrooxypropanol (NOP)/ $\mathrm{kg}$ of $\mathrm{DM}^{1}$

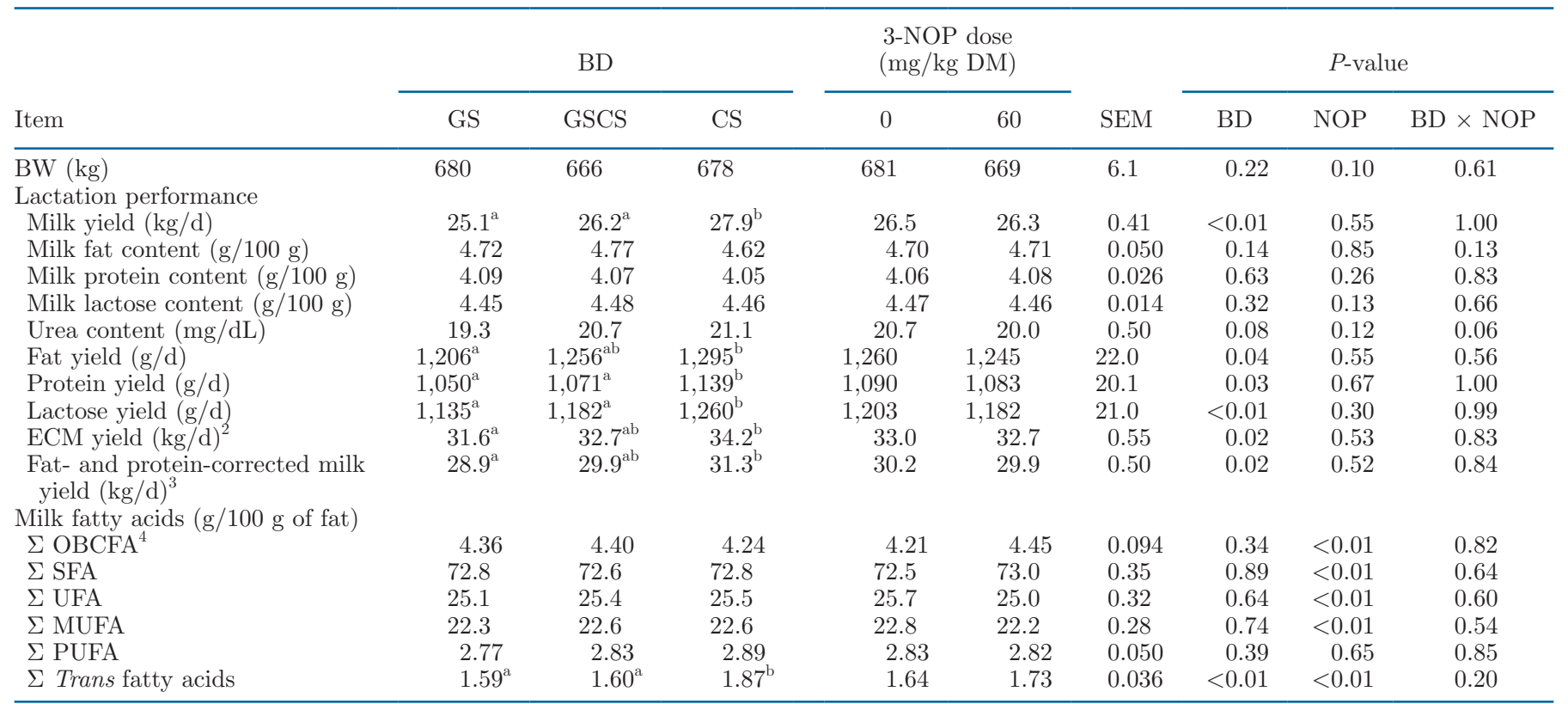

${ }^{\mathrm{a}, \mathrm{b}}$ Values with a different superscript indicate a significant $(P<0.05)$ difference between the BD.

${ }^{1}$ Milk yield $(\mathrm{kg} / \mathrm{d})$ was determined daily. Milk composition (content as well as yield of major components), ECM yield, and fat- and proteincorrected milk yield were determined on a weekly basis.

${ }^{2} \mathrm{ECM}=[$ milk yield $(\mathrm{kg} / \mathrm{d}) \times 0.327]+[$ fat yield $(\mathrm{kg} / \mathrm{d}) \times 12.95]+[$ protein yield $(\mathrm{kg} / \mathrm{d}) \times 7.25]($ Tyrrell and Reid, 1965).

${ }^{3}$ Fat- and protein-corrected milk $=[0.337+0.116 \times$ fat $(\mathrm{g} / 100 \mathrm{~g})+0.06 \times$ protein $(\mathrm{g} / 100 \mathrm{~g})] \times$ milk yield $(\mathrm{kg} / \mathrm{d})(\mathrm{CVB}, 2018)$.

${ }^{4}$ Sum of all odd- and branched-chain fatty acids (i.e., iso C14:0, iso $\mathrm{C} 15: 0$, anteiso $\mathrm{C} 15: 0, \mathrm{C} 15: 0$, iso $\mathrm{C} 16: 0$, iso $\mathrm{C} 17: 0$, anteiso $\mathrm{C} 17: 0$, and $\mathrm{C} 17: 0$ ). 
Table 8. Body weight and lactation characteristics of lactating dairy cows fed different basal diets (BD; where GS = grass silage-based diet, GSCS = grass silage- and corn silage-mixed diet, $\mathrm{CS}=$ corn silage-based diet) supplemented with 0 or $80 \mathrm{mg}$ of 3-nitrooxypropanol (NOP)/ $\mathrm{kg}$ of $\mathrm{DM}^{\mathrm{P}}$

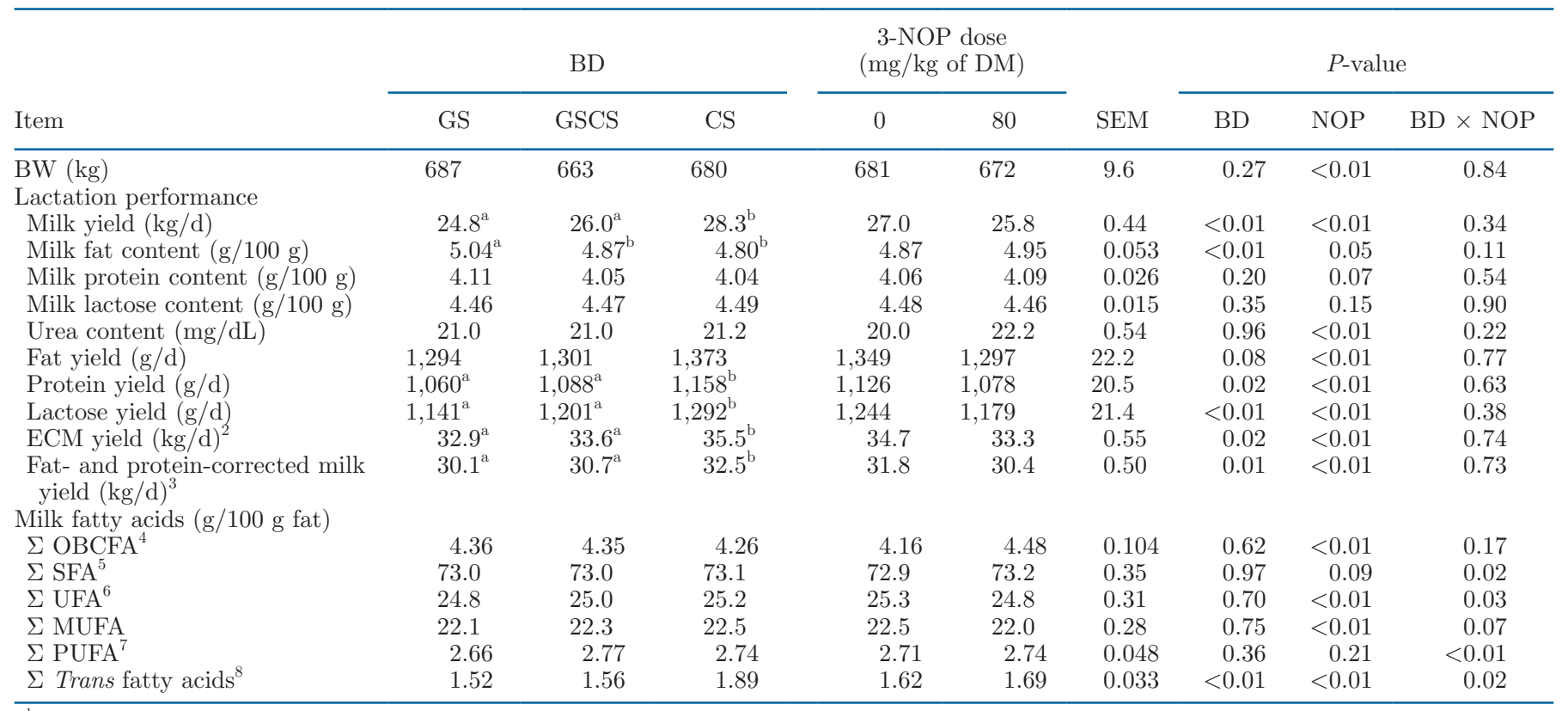

${ }^{\mathrm{a}, \mathrm{b}}$ Values with a different superscript indicate a significant $(P<0.05)$ difference between the BD.

${ }^{1}$ Milk yield $(\mathrm{kg} / \mathrm{d})$ was determined daily. Milk composition (content as well as yield of major components), ECM yield, and fat- and proteincorrected milk yield were determined on a weekly basis.

${ }^{2} \mathrm{ECM}=[$ milk yield $(\mathrm{kg} / \mathrm{d}) \times 0.327]+[$ fat yield $(\mathrm{kg} / \mathrm{d}) \times 12.95]+[$ protein yield $(\mathrm{kg} / \mathrm{d}) \times 7.25]$ (Tyrrell and Reid, 1965).

${ }^{3}$ Fat- and protein-corrected milk $=[0.337+0.116 \times$ fat $(\mathrm{g} / 100 \mathrm{~g})+0.06 \times$ protein $(\mathrm{g} / 100 \mathrm{~g})] \times$ milk yield $(\mathrm{kg} / \mathrm{d})(\mathrm{CVB}, 2018)$.

${ }^{4} \mathrm{Sum}$ of all odd- and branched-chain fatty acids (i.e., iso C14:0, iso C15:0, anteiso C15:0, C15:0, iso C16:0, iso C17:0, anteiso C17:0, and C17:0). ${ }^{5} \mathrm{BD} \times \mathrm{NOP}$ interaction; GS NOP0 $=72.6^{\mathrm{v}}$, GS NOP $80=73.5^{\mathrm{w}}$, GSCS NOP0 $=72.7^{\mathrm{vw}}$, GSCS NOP $80=73.3^{\mathrm{vw}}, \mathrm{CS}$ NOP0 $=73.3^{\mathrm{vw}}$, and CS $\mathrm{NOP} 80=72.9^{\mathrm{vw}}$. Different superscripts indicate a significant $(P<0.05)$ difference.

${ }^{6} \mathrm{BD} \times$ NOP interaction; GS NOP0 $=25.3^{\mathrm{vx}}$, GS NOP $80=24.3^{\mathrm{w}}$, GSCS NOP0 $=25.4^{\mathrm{x}}$, GSCS NOP $80=24.7^{\mathrm{vw}}$, CS NOP0 $=25.1^{\mathrm{vwx}}$, and CS NOP $80=25.3^{\mathrm{vwx}}$. Different superscripts indicate a significant $(P<0.05)$ difference.

${ }^{7} \mathrm{BD} \times \mathrm{NOP}$ interaction; GS NOP0 $=2.68^{\mathrm{vw}}$, GS NOP $80=2.64^{\mathrm{v}}$, GSCS NOP0 $=2.78^{\mathrm{vw}}$, GSCS NOP $80=2.76^{\mathrm{vw}}, \mathrm{CS}$ NOP0 $=2.67^{\mathrm{v}}$, and $\mathrm{CS}$ NOP $80=2.81^{\mathrm{w}}$. Different superscripts indicate a significant $(P<0.05)$ difference.

${ }^{8} \mathrm{BD} \times \mathrm{NOP}$ interaction; GS NOP0 $=1.52^{\mathrm{v}}$, GS NOP $80=1.53^{\mathrm{v}}$, GSCS NOP0 $=1.54^{\mathrm{v}}$, GSCS NOP $80=1.58^{\mathrm{v}}, \mathrm{CS}$ NOP0 $=1.80^{\mathrm{w}}$, and CS NOP 80 $=1.97^{\mathrm{x}}$. Different superscripts indicate a significant $(P<0.05)$ difference.

2019; van Gastelen et al., 2020) reported no significant effects of 3 -NOP on lactation characteristics and feed intake, the time needed to alter these variables by a change in 3-NOP dose could be longer than that needed to alter $\mathrm{CH}_{4}$ emission. Hence, we ensured that an adaptation period of $1 \mathrm{wk}$ or more was adopted upon a change in 3-NOP dose. This short step up and adaptation approach has been used previously in beef studies with 3-NOP (Alemu et al., 2021).

\section{$\mathrm{CH}_{4}$ Emissions}

From 2014 onward, many studies reported that 3-NOP effectively reduces $\mathrm{CH}_{4}$ emissions in dairy cattle (e.g., Haisan et al., 2014, 2017; Hristov et al., 2015a; Lopes et al., 2016; Melgar et al., 2020b), as well as that the $\mathrm{CH}_{4}$ mitigation of $3-\mathrm{NOP}$ in dairy cattle is persistent over time (Hristov et al., 2015a; Melgar et al., 2020b, 2021; van Gastelen et al., 2020). In the present study, 3-NOP supplementation (either 60 or $80 \mathrm{mg}$ / $\mathrm{kg}$ of $\mathrm{DM}$ ) resulted in reduced $\mathrm{CH}_{4}$ emissions relative to NOP0 for all 3 different BD. For both dosages of 3 -NOP and for all 3 measures of $\mathrm{CH}_{4}$ emission, the mitigating effect of 3-NOP was, however, smaller when supplemented to the GS diet compared with the GSCS and CS diets. In the present study, dietary starch content increased from, on average taking both crossovers into account, $98 \mathrm{~g} / \mathrm{kg}$ of DM in the GS diet, to $154 \mathrm{~g} / \mathrm{kg}$ of DM in the GSCS diet, to $212 \mathrm{~g} / \mathrm{kg}$ of DM in the CS diet. Vyas et al. (2018) hypothesized that feeding diets with a greater starch content would result in smaller concentrations of methyl-coenzyme $\mathrm{M}$ reductase in the rumen. Greater levels of dietary starch generally result in a low ruminal pH (Van Kessel and Russell, 1996), inhibiting methanogens and inducing changes in the methanogenic populations present (Grainger and 
Beauchemin, 2011), contributing to smaller levels of methyl-coenzyme $\mathrm{M}$ reductase. Consequently, it can be proposed that adding 3-NOP might inhibit methyl-coenzyme $\mathrm{M}$ reductase with a greater efficacy, resulting in a greater mitigation potential of 3-NOP, in diets with a greater starch content (although the precise mechanism behind this remains unclear).

It should be noted that not only the dietary starch content differed between the $\mathrm{BD}$, but also the dietary $\mathrm{CP}$ content and the 3-NOP dose (and subsequently intake of 3-NOP). Metabolizable protein allowance was, however, above calculated requirements for the dairy cows and the diets were designed to have a similar metabolizable protein content across the diets. Hence, the difference in dietary $\mathrm{CP}$ content among the $3 \mathrm{BD}$ in the present study is not expected to significantly affect $\mathrm{CH}_{4}$ emission or the $\mathrm{CH}_{4}$ mitigation potential of 3-NOP. The 3-NOP dose in the present study was slightly smaller for the GS diets compared with the GSCS and CS diets in both crossovers. Although Hristov et al. (2015a; 3 -NOP doses tested were 40,60 , and $80 \mathrm{mg} / \mathrm{kg}$ of DM) reported no effect of 3-NOP dose on $\mathrm{CH}_{4}$ mitigation, both Reynolds et al. (2014; 3-NOP doses tested were 500 and 2,500 mg/d) and Melgar et al. (2020a; 3-NOP doses tested were $40,60,80,100,150$, and $200 \mathrm{mg} / \mathrm{kg}$ of DM) reported that reduction in $\mathrm{CH}_{4}$ emissions was dose dependent. Hence, it is expected that a smaller 3-NOP dose may have resulted in a less pronounced decline in $\mathrm{CH}_{4}$ emissions. Dijkstra et al. (2018) concluded that $\mathrm{CH}_{4}$ yield was decreased by $2.48 \pm 0.734 \%$ per $10 \mathrm{mg} /$ $\mathrm{kg}$ of DM increase in the 3-NOP dose from its mean. In the present study, the 3 -NOP dose was 9 and $12 \mathrm{mg} / \mathrm{kg}$ of DM lower for the GS diet compared with the CS diet in the crossovers with NOP60 and NOP80, respectively. According to Dijkstra et al. (2018), these differences in 3 -NOP dose would result in a 2.2 to $3.0 \%$ difference, respectively, in $\mathrm{CH}_{4}$ mitigation between the GS and CS diet. This is not sufficient, however, to account for the actual observed declines in $\mathrm{CH}_{4}$ emissions between the GS, GSCS and CS diets for both NOP60 and NOP80.

\section{$\mathrm{H}_{2}$ and $\mathrm{CO}_{2}$ Emissions}

The measured increase in $\mathrm{H}_{2}$ emission upon 3-NOP supplementation was only a fraction of the stoichiometric amount involved with the decrease in $\mathrm{CH}_{4}$ production as $\mathrm{H}_{2}$ sink. This may have been caused by the method used to measure $\mathrm{H}_{2}$ emission. Van Lingen et al. (2017) showed that $\mathrm{H}_{2}$ emissions were a factor 100 greater in the first hour after a meal. If an animal does not visit the GreenFeed units in this first hour after a meal, we miss this large amount of $\mathrm{H}_{2}$ emission in our daily estimate. Hence, we may have underestimated $\mathrm{H}_{2}$ production, because of the large (i.e., 100-fold) fluctua- tion in $\mathrm{H}_{2}$ production within a day. However, a smaller measured increase in $\mathrm{H}_{2}$ emission than the calculated amount of unused $\mathrm{H}_{2}$ due to decreased $\mathrm{CH}_{4}$ production was also observed by studies using different $\mathrm{H}_{2}$ measurement techniques, namely Hristov et al. (2015a; used the GreenFeed system and $\mathrm{SF}_{6}$-tracer technique) and van Gastelen et al. (2020; used climate respiration chambers). This suggests that next to 3 -NOP reducing $\mathrm{CH}_{4}$ emissions, the secondary effects of 3-NOP likely include a redirection of $\mathrm{H}_{2}$ to alternative $\mathrm{H}_{2}$ sinks, with a redirection of the rumen fermentation profile toward propionate fermentation being most likely (Haisan et al., 2014; Lopes et al., 2016).

The BD $\times$ NOP interaction observed for the fold increase in $\mathrm{H}_{2}$, indicating a greater fold increase when 3-NOP was supplemented to CS compared with GS, is generally in line with the $\mathrm{CH}_{4}$ emissions results discussed earlier. The increase in $\mathrm{H}_{2}$ emissions upon 3 -NOP supplementation is in line with the findings of Hristov et al. (2015a), Lopes et al. (2016), Melgar et al. (2020a, 2020b), and van Gastelen et al. (2020). The observed absolute increase in $\mathrm{H}_{2}$ production $(\mathrm{g} / \mathrm{d})$ in the present study with 3-NOP supplementation ranged between $5.91 \mathrm{~g} / \mathrm{d}(\mathrm{NOP} 60)$ and $6.39 \mathrm{~g} / \mathrm{d}$ (NOP80). These levels are, when expressed relative to DMI, somewhat less than those reported by van Gastelen et al. (2020; $3-\mathrm{NOP}=60 \mathrm{mg} / \mathrm{kg}$ of DM), but far greater than those measured by Hristov et al. (2015a; $3-\mathrm{NOP}=80 \mathrm{mg} / \mathrm{kg}$ of DM), Lopes et al. (2016; 3-NOP $=60 \mathrm{mg} / \mathrm{kg}$ of DM), Melgar et al. (2020a; 3-NOP $=80 \mathrm{mg} / \mathrm{kg}$ of DM), and Melgar et al. (2020b; 3-NOP $=60 \mathrm{mg} / \mathrm{kg}$ of DM). van Gastelen et al. (2020), the only study using climate respiration chambers rather than the GreenFeed system, suggested that these differences were most likely caused by the measurement technique and the experimental design. This, however, appears not to be the only reason, because in the present study we also used the GreenFeed system to measure $\mathrm{H}_{2}$ production and we obtained results more comparable, though still somewhat less pronounced, to those obtained with the climate respiration chambers. We therefore presume that the feeding schedule as well as the sampling scheme must have played an essential role in the level of $\mathrm{H}_{2}$ emissions measured. Fresh feed was offered 3 times daily in equal portions in the current study, whereas it was delivered once daily (but pushed up to the cows several times daily) in the above-mentioned studies (i.e., Hristov et al., 2015a; Lopes et al., 2016; Melgar et al., 2020a, 2020b). Additionally, all above-mentioned studies used the fixed sampling scheme as proposed by Hristov et al. (2015a) at 0900, 1500, and $2100 \mathrm{~h}$ (sampling d 1), 0300, 1200, and $1700 \mathrm{~h}$ (sampling d 2), and 0000 and $0500 \mathrm{~h}$ (sampling d 3) to obtain a representative sample of a 24-h feeding cycle. In the current study, the dairy 
cows had free access to the GreenFeed units throughout the day and each day of the experiment (i.e., $13 \mathrm{wk}$ ). In Supplemental Figures S1 and S2 (https://doi.org/ 10.17632/2nfwrtc44s.1; van Gastelen, 2022a), we illustrate that the voluntary visits to the GreenFeed units are well spread over a 24 -h period in both crossovers. Nevertheless, it remains unclear how these visits relate to the FB visits and feeding behavior (e.g., meal size) of the dairy cows as well as to the measured emissions of $\mathrm{H}_{2}$. To a far smaller extent such effects are to be expected on $\mathrm{CH}_{4}$ emissions, because fluctuation in $\mathrm{CH}_{4}$ production within a day are considerably smaller than those in $\mathrm{H}_{2}$ production (van Lingen et al., 2017).

In both crossovers, the production of $\mathrm{CO}_{2}$ was not affected by BD despite differences in DMI. The decreased $\mathrm{CO}_{2}$ yield for the CS diet compared with the GS diet is not in line with the observed response in $\mathrm{CH}_{4}$ yield, and cannot be explained because the measured $\mathrm{CO}_{2}$ emission is a sum of many different processes. The decreased $\mathrm{CO}_{2}$ production for NOP80 compared with NOP0 may have been caused by the lower DMI, and is in agreement with Melgar et al. (2020b) who observed a decreased $\mathrm{CO}_{2}$ production upon 3-NOP supplementation in early-lactation dairy cows, but contrary to Hristov et al. (2015a) who did not observe differences in $\mathrm{CO}_{2}$ emissions upon 3-NOP supplementation in midto late-lactation dairy cows. The increased $\mathrm{CO}_{2}$ yield for NOP60 as well as NOP80 compared with NOP0 is likely related to $\mathrm{CO}_{2}$ being used in $\mathrm{CH}_{4}$ formation. Assuming that in methanogenesis $1 \mathrm{~mol} \mathrm{CO}_{2}$ is used to form $1 \mathrm{~mol} \mathrm{CH}_{4}$ (McAllister and Newbold, 2008), the $6.2 \mathrm{~g}$ of $\mathrm{CH}_{4} / \mathrm{kg}$ of DMI decrease at NOP60 compared with NOP0, corresponds in theory with an increase of $17 \mathrm{~g}$ of $\mathrm{CO}_{2} / \mathrm{kg}$ of DMI at NOP60. We observed that $\mathrm{CO}_{2}$ yield increased with $18 \mathrm{~g} / \mathrm{kg}$ of DMI. Similarly, at NOP80, an increase of $19 \mathrm{~g}$ of $\mathrm{CO}_{2} / \mathrm{kg}$ of DMI compared with NOP0 could be expected, where we observed an increase of $28 \mathrm{~g}$ of $\mathrm{CO}_{2} / \mathrm{kg}$ of DMI. Hence, it is safe to say that a large part of the observed increase in $\mathrm{CO}_{2}$ yield may be explained by the lower $\mathrm{CH}_{4}$ yield.

\section{Feed Intake}

Irrespective of the $\mathrm{BD}$, feeding 3-NOP, at both 60 and $80 \mathrm{mg} / \mathrm{kg}$ of DM, resulted in a decreased total DMI as well as DMI of the partially mixed ration compared with $0 \mathrm{mg} 3-\mathrm{NOP} / \mathrm{kg}$ of DM. Kim et al. (2020) performed a meta-analysis and reported that the DMI of beef cattle tended to decrease when the dose of 3-NOP increased, whereas no significant effect on DMI was found for dairy cattle. The latter is because none of the individual studies used for that meta-analysis reported a significant change of DMI by 3-NOP. Melgar et al. (2020a) reported that overall DMI was not different be- tween 3-NOP and control, but did observe that increasing the 3-NOP dose tended to linearly decrease DMI. Melgar et al. (2020b) reported, similar to the present study, a decreased DMI upon 3-NOP supplementation. The decreased DMI might be the result of an increased ruminal propionate production at the expense of ruminal acetate upon feeding 3-NOP, as indicated by the differences in rumen molar proportions of these acids reported by others (e.g., Reynolds et al., 2014; Haisan et al., 2016; Lopes et al., 2016). Increased portal vein propionate concentrations, arising from increased production of VFA as well as an increased propionate molar proportion, can promote satiety, resulting in a decrease in DMI (Allen, 2000; Stocks and Allen, 2012). Alternatively, the decreased DMI may also indicate that the rumen microbiota were not able to cope with excess of $\mathrm{H}_{2}$ formed with NOP80, because an increased partial pressure of $\mathrm{H}_{2}$ in the rumen is expected to inhibit metabolism of rumen microorganisms (McAllister and Newbold, 2008; Morgavi et al., 2010). Although such an inhibitory effect of $\mathrm{H}_{2}$ cannot be excluded, it is worth reminding that normal postprandial fluctuations in rumen $\mathrm{H}_{2}$ are also large (a factor of 100; van Lingen et al., 2017).

The CS diet resulted in increased total DMI as well as DMI of the partially mixed ration compared with GS. Even though studies differ in experimental design (i.e., some studies replaced grass silage with corn silage without changing the composition of the concentrate and other studies changed the composition of both the ratio between grass silage and corn silage and the composition of concentrates), many reported positive effects of CS on feed intake (e.g., Abrahamse et al., 2008b; Kliem et al., 2008; van Gastelen et al., 2015; Günal et al., 2019). The reason behind the effect of BD on DMI of the GreenFeed bait and the number of visits to the GreenFeed units remains unclear, but could be related to the content difference in glucogenic precursors or rapidly fermentable substrates in the BD.

\section{Body Weight and Lactation Performance}

Irrespective of the $\mathrm{BD}$, dairy cows in the present study had a lower BW when 3-NOP was fed compared with when no 3-NOP was fed (for NOP60, tendency only), likely related to the smaller DMI with subsequently less feed in the GIT and digesta weight content. It is interesting that NOP60 did not affect milk yield and composition, whereas almost all milk performance characteristics were affected by NOP80. Although we statistically should not compare the 2 dosages of 3 -NOP because of the design of the experiment (i.e., NOP60 and NOP80 were not fed simultaneously), these results suggest a negative dose response relationship 
between 3-NOP dose and milk performance. Hristov et al. (2015a) reported a quadratic response of 3-NOP on milk protein and lactose yield, which were smaller for $80 \mathrm{mg}$ of $3-\mathrm{NOP} / \mathrm{kg}$ of DM (high dose) compared with $60 \mathrm{mg}$ of $3-\mathrm{NOP} / \mathrm{kg}$ of $\mathrm{DM}$ (medium dose). Additionally, Melgar et al. (2020a) reported a trend for a linear decrease in milk yield as well as a significant linear increase in milk fat yield with increase of 3-NOP dose (ranging from 40 to $200 \mathrm{mg}$ of $3-\mathrm{NOP} / \mathrm{kg}$ of $\mathrm{DM}$ ). In the recent study, the observed decrease in the yield of the major milk components (i.e., fat, protein, and lactose) as well as ECM and FPCM at NOP80 appears to be the direct result of the decrease in milk yield, and a rather unaffected milk composition. The effect of 3 -NOP on milk yield is likely related to the decreased dietary energy supply observed upon feeding 3-NOP. Compared with no 3-NOP supplementation, the decrease in total DMI was $0.6 \mathrm{~kg} / \mathrm{d}$ for NOP60, representing a decrease of $2.5 \%$. For NOP80, total DMI decreased with $1.3 \mathrm{~kg} / \mathrm{d}$, representing a decrease of $6.5 \%$. The difference in DMI decrease may explain the observed effects of 3 -NOP on the lactational performance with NOP80 and lack of these effects with NOP60. Melgar et al. (2020b) reported increased milk urea nitrogen concentrations when 3-NOP was fed $(60$ $\mathrm{mg} / \mathrm{kg}$ of DM), whereas Reynolds et al. (2014; 27 and $135 \mathrm{mg}$ of $3-\mathrm{NOP} / \mathrm{kg}$ of $\mathrm{DM})$, Lopes et al. (2016; 60 $\mathrm{mg}$ of $3-\mathrm{NOP} / \mathrm{kg}$ of DM), Haisan et al. (2016; 68 and $132 \mathrm{mg}$ of $3-\mathrm{NOP} / \mathrm{kg}$ of $\mathrm{DM}$ ) and van Gastelen et al. (2020; $60 \mathrm{mg}$ of 3-NOP/ $\mathrm{kg}$ of DM) reported no effect of 3 -NOP on milk urea nitrogen. It remains unclear why in the present study the larger 3-NOP dose resulted in increased milk urea content, whereas the smaller 3-NOP dose did not.

The total concentration of SFA in MFA increased when NOP60 was supplemented to all BD, but for NOP80 only when supplemented to GS. The increase in SFA with <16C agrees with Hristov et al. (2015a), Melgar et al. (2020a), and van Gastelen et al. (2020), but is contrary to Reynolds et al. (2014). The SFA with $<16 \mathrm{C}$ are generally synthesized de novo in the mammary gland primarily from acetate (Bauman and Griinari, 2003) and indirectly from butyrate (Dijkstra et al., 2011). Others consistently report increased molar proportions of propionate at the expense of molar proportions of acetate in rumen fluid with feeding of 3-NOP [e.g., Haisan et al., (2014) and Lopes et al. (2016), both studies reported no effect of 3-NOP on total VFA]. A decrease in ruminal molar proportion of acetate may be accompanied with an increase in molar proportions of ruminal butyrate, as reported by Melgar et al. (2020b), and may have been used as primer for synthesis of SFA with $<16 \mathrm{C}$ (Bauman and Griinari, 2003). Irrespective of the BD composition, the total concentration of OBCFA in milk fat increased with 3-NOP supplementation, with in general iso-C14:0 and iso-C16:0 decreasing and with $\mathrm{C} 15: 0$, anteiso-C15:0, $\mathrm{C} 17: 0$, and anteiso-C17:0 increasing (Supplemental Tables S1 and S2). Lopes et al. (2016) reported an increase in ruminal molar proportions of propionate and in the relative abundance of propionate producing bacteria when 3-NOP was fed to dairy cows. Propionate is a substrate for de novo synthesis of several odd-chain fatty acids, including C15:0 and C17:0 in the mammary gland (van Gastelen and Dijkstra, 2016). Additionally, milk OBCFA are of microbial origin in the rumen, with anteiso OBCFA more abundant in amylolytic bacteria and iso OBCFA more abundant in fibrolytic bacteria (Vlaeminck et al., 2006). Upon feeding 3-NOP to dairy cows, Lopes et al. (2016) reported increased relative abundance of amylolytic bacteria, such as Butyrivibrio, and decreased relative abundance of fibrolytic bacteria, such as Ruminococcus spp. The changes upon 3-NOP supplementation in anteiso and iso MFA observed in the present experiment are in line with these shifts in abundance of amylolytic and fibrolytic bacteria. The increase of the sum of trans MFA upon 3-NOP supplementation (for NOP60 with all BD and for NOP80 only for CS) suggest that the biohydrogenation pathway has been modified or that the biohydrogenation activity in the rumen has changed upon 3-NOP supplementation, potentially because of changes in ruminal $\mathrm{pH}$. The effects of 3-NOP on ruminal $\mathrm{pH}$ are, however, not consistently reported in literature. Haisan et al. (2016) and Lopes et al. (2016) reported no effects of 3-NOP on ruminal pH, whereas Melgar et al. (2020b) observed a greater ruminal $\mathrm{pH}$ upon feeding 3-NOP.

The increased milk yield, ECM, and FPCM for CS compared with GS is contrary to some studies (e.g., Abrahamse et al., 2008b; Brask et al., 2013; Günal et al., 2019; studies where grass silage was replaced with corn silage, without changing concentrate composition), but in agreement with Kliem et al. (2008; study where composition of both forage and concentrate was changed). The observed effects of $\mathrm{BD}$ on lactational performance is likely related to the observed increase in DMI for CS compared with GS, which represents an increased feed energy availability for milk production. The observed increase in milk protein yield with CS compared with GS appears to be the result of the increased milk yield in combination with an unaffected milk protein content. Generally, an increased intake of readily digestible carbohydrates, such as starch, and decreased intake of fibrous components is associated with a reduction in milk fat production (Lock and Shingfield, 2004; Nielsen et al., 2006). This is due to the decrease in the molar proportion of acetate and increase in that of propionate (Bannink et al., 2006), and 
a lower ruminal $\mathrm{pH}$ which also favors a smaller acetate to propionate ratio (van Soest, 1994), and formation of specific trans fatty acids in the rumen (Bauman and Griinari, 2003). Feeding corn silage-based diets compared with grass silage-based diets is, however, not always associated with a significant reduction of milk fat production, probably due to variation in feeding quality of these silages. Fitzgerald and Murphy (1999) for example reported no effect on milk fat production, which according to the authors was partly caused by the reduction in digestibility for the corn silage-based diet compared with the grass silage-based diet. Kliem et al. (2008), on the other hand, reported no effect on milk fat production, which according to the authors was related to the relatively low dietary starch content and high NDF content in the corn silage-based diet. The latter also seems valid for the present study, where the dietary NDF content was rather similar for all diets and the dietary starch content was only slightly above $200 \mathrm{~g} / \mathrm{kg}$ of DM for CS. This may explain why milk fat yield actually increased in both crossovers and why milk fat content was only smaller for CS compared with GS in the crossover with 0 and $80 \mathrm{mg}$ of $3-\mathrm{NOP} / \mathrm{kg}$ of DM (i.e., $-4.8 \%$ only).

The BD composition did not affect the groups of MFA, except for trans fatty acids, which is in agreement with Kliem et al. (2008), and van Gastelen et al. (2015). The increase in trans MFA for CS compared with GS is likely a result of reduced ruminal $\mathrm{pH}$ upon feeding high levels of dietary starch (Brask et al., 2013), affecting shifts in the ruminal microbial population that are associated with modifications in the biohydrogenation pathways. The unaffected SFA suggest that de novo synthesis of milk fatty acids in the mammary gland was unaffected. This could indicate that ruminal acetate and butyrate, the major carbon sources for de novo synthesized FA (Bauman and Griinari, 2003), remained unaffected by the BD composition.

\section{CONCLUSIONS}

Interactions between the $\mathrm{BD}$ and 3 -NOP were observed for the production (g/d) and yield (g/kg DMI) of both $\mathrm{CH}_{4}$ and $\mathrm{H}_{2}$, indicating that the mitigating effect of 3-NOP depended on the composition of the BD. Emissions of $\mathrm{CH}_{4}$ decreased upon 3-NOP supplementation for all $\mathrm{BD}$, but the decrease in $\mathrm{CH}_{4}$ emissions was smaller for GS compared with GSCS and CS, with no difference between the latter $2 \mathrm{BD}$. The increase in $\mathrm{H}_{2}$ emissions upon 3-NOP supplementation followed a similar pattern. The CS diet resulted in larger DMI, milk yield, and the yield of major milk components. Feeding 3 -NOP resulted in a decreased DMI, but did not affect feed efficiency (both for NOP60 and NOP80). Milk yield and composition did not differ between NOP60 and NOP0, whereas milk yield and the yield of major components were smaller for NOP80 compared with NOP0. It is therefore concluded that 3-NOP can effectively decrease $\mathrm{CH}_{4}$ emissions in dairy cows across diets, but the level of $\mathrm{CH}_{4}$ mitigation is greater when supplemented in CS compared with a GS.

\section{ACKNOWLEDGMENTS}

This project was financed by DSM Nutritional Products (Basel, Switzerland) and co-financed by the Samenwerkingsverband Noord-Nederland (SNN), Ruimtelijk Economisch Programma, performed at the dairy research facility Dairy Campus (Leeuwarden, the Netherlands). The staff of Dairy Campus (Leeuwarden, the Netherlands), in particular Fedde de Jong, Martin de Bree, Ebele Visser, Hans Hylkema, and Bert Klandermans, are acknowledged for their assistance during the implementation of the experiment, as are the laboratory staff of the Animal Nutrition Group (Wageningen, the Netherlands) for all chemical analysis, Katrien Schäfer of DSM Nutritional Products (Kaiseraugst, Switzerland) for the in-feed analysis of 3-NOP, and Alex Karagiannis-Voules of DSM Nutritional Products (Kaiseraugst, Switzerland) for support on data analysis and statistics. The authors have not stated any conflicts of interest.

\section{REFERENCES}

Abrahamse, P. A., J. Dijkstra, B. Vlaeminck, and S. Tamminga. 2008a. Frequent allocation of rotationally grazed dairy cows changes grazing behavior and improves productivity. J. Dairy Sci. 91:20332045. https://doi.org/10.3168/jds.2007-0579.

Abrahamse, P. A., B. Vlaeminck, S. Tamminga, and J. Dijkstra. $2008 \mathrm{~b}$. The effect of silage and concentrate type on intake behavior, rumen function, and milk production in dairy cows in early and late lactation. J. Dairy Sci. 91:4778-4792. https://doi.org/10 .3168/jds.2008-1350.

Alemu, A. W., A. L. Shreck, C. W. Booker, S. M. McGinn, L. K. D. Pekrul, M. Kindermann, and K. A. Beauchemin. 2021. Use of 3-nitrooxypropanol in a commercial feedlot to decrease enteric methane emissions from cattle fed a corn-based finishing diet. J. Anim. Sci. 99:skaa394. https://doi.org/10.1093/jas/skaa394.

Allen, M. S. 2000. Effects of diet on short-term regulation of feed intake by lactating dairy cattle. J. Dairy Sci. 83:1598-1624. https:// doi.org/10.3168/jds.S0022-0302(00)75030-2.

Bannink, A., J. Kogut, J. Dijkstra, J. France, E. Kebreab, A. M. Van Vuuren, and S. Tamminga. 2006. Estimation of the stoichiometry of volatile fatty acid production in the rumen of lactating cows. J. Theor. Biol. 238:36-51. https://doi.org/10.1016/j.jtbi.2005.05.026.

Bauman, D. E., and J. M. Griinari. 2003. Nutritional regulation of milk fat synthesis. Annu. Rev. Nutr. 23:203-227. https://doi.org/ 10.1146/annurev.nutr.23.011702.073408.

Beauchemin, K. A., M. Kreuzer, F. O'Mara, and T. A. McAllister. 2008. Nutritional management for enteric methane abatement: A review. Aust. J. Exp. Agric. 48:21-27. https://doi.org/10.1071/ EA07199.

Brask, M., P. Lund, A. L. F. Hellwing, M. Poulsen, and M. R. Weisbjerg. 2013. Enteric methane production, digestibility and rumen 
fermentation in dairy cows fed different forages with and without rapeseed fat supplementation. Anim. Feed Sci. Technol. 184:67-79. https://doi.org/10.1016/j.anifeedsci.2013.06.006.

CVB (Centraal Veevoederbureau). 2018. Chemische Samenstellingen en Nutritionele Waarden van Voedermiddelen (in Dutch). CVB.

Dijkstra, J., A. Bannink, J. France, E. Kebreab, and S. van Gastelen. 2018. Short communication: Antimethanogenic effects of 3-nitrooxypropanol depend on supplementation dose, dietary fiber content, and cattle type. J. Dairy Sci. 101:9041-9047. https://doi.org/ 10.3168/jds.2018-14456.

Dijkstra, J., S. M. van Zijderveld, J. A. Apajalahti, A. Bannink, W. J. J. Gerrits, J. R. Newbold, H. B. Perdok, and H. Berends. 2011. Relationships between methane production and milk fatty acid profiles in dairy cattle. Anim. Feed Sci. Technol. 166-167:590-595. https://doi.org/10.1016/j.anifeedsci.2011.04.042.

Duin, E. C., T. Wagner, S. Shima, D. Prakash, B. Cronin, D. R. Yáñez-Ruiz, S. Duval, R. Rümbeli, R. T. Stemmler, R. K. Thauer, and M. Kindermann. 2016. Mode of action uncovered for the specific reduction of methane emissions from ruminants by the small molecule 3-nitrooxypropanol. Proc. Natl. Acad. Sci. USA 113:6172-6177. https://doi.org/10.1073/pnas.1600298113.

Fitzgerald, J. J., and J. J. Murphy. 1999. A comparison of low starch maize silage and grass silage and the effect of concentrate supplementation of the forages or inclusion of maize grain with the maize silage on milk production by dairy cows. Livest. Prod. Sci. 57:95111. https://doi.org/10.1016/S0301-6226(98)00200-0.

Grainger, C., and K. Beauchemin. 2011. Can enteric methane emissions from ruminants be lowered without lowering their production? Anim. Feed Sci. Technol. 166-167:308-320. https://doi.org/ 10.1016/j.anifeedsci.2011.04.021.

Günal, M., A. McCourt, Y. Zhao, Z. G. Yan, and T. Yan. 2019. The effect of silage type on animal performance, energy utilisation and enteric methane emission in lactating dairy cows. Anim. Prod. Sci. 59:499-505. https://doi.org/10.1071/AN16435.

Haisan, J., Y. Sun, L. L. Guan, K. A. Beauchemin, A. Iwaasa, S. Duval, D. R. Barreda, and M. Oba. 2014. The effects of feeding 3-nitrooxypropanol on methane emissions and productivity of Holstein cows in mid lactation. J. Dairy Sci. 97:3110-3119. https://doi.org/ 10.3168/jds.2013-7834.

Haisan, J. Y., Y. Sun, L. Guan, K. A. Beauchemin, A. Iwaasa, S. Duval, M. Kindermann, D. R. Barreda, and M. Oba. 2016. The effects of feeding 3-nitrooxypropanol at two doses on milk production, rumen fermentation, plasma metabolites, nutrient digestibility, and methane emissions in lactating Holstein cows. Anim. Prod. Sci. 57:282-289. https://doi.org/10.1071/AN15219.

Hammond, K. J., D. J. Humphries, L. A. Crompton, C. Green, and C. K. Reynolds. 2015. Methane emissions from cattle: Estimates from short-term measurements using a GreenFeed system compared with measurements obtained using respiration chambers or sulphur hexafluoride tracer. Anim. Feed Sci. Technol. 203:41-52. https://doi.org/10.1016/j.anifeedsci.2015.02.008.

Hristov, A. N., J. Oh, J. L. Firkins, J. Dijkstra, E. Kebreab, G. Waghorn, H. P. S. Makkar, A. T. Adesogan, W. Yang, C. Lee, P. J. Gerber, B. Henderson, and J. M. Tricarico. 2013. Mitigation of methane and nitrous oxide emissions from animal operations: I. A review of enteric methane mitigation options. J. Anim. Sci. 91:5045-5069. https://doi.org/10.2527/jas.2013-6583.

Hristov, A. N., J. Oh, F. Giallongo, T. Frederick, H. Weeks, P. R. Zimmerman, M. T. Harper, R. A. Hristova, S. R. Zimmerman, and A. F. Branco. 2015b. The use of an automated system (GreenFeed) to monitor enteric methane and carbon dioxide emissions from ruminant animals. J. Vis. Exp. 103:e52904. https://doi.org/10.3791/ 52904.

Hristov, A. N., J. Oh, F. Giallongo, T. W. Frederick, M. T. Harper, H. L. Weeks, A. F. Branco, P. J. Moate, M. H. Deighton, S. R. O. Williams, M. Kindermann, and S. Duval. 2015a. An inhibitor persistently decreased enteric methane emission from dairy cows with no negative effect on milk production. Proc. Natl. Acad. Sci. USA 112:10663-10668. https://doi.org/10.1073/pnas.1504124112.

International Organization for Standardization. 1998. ISO 9831:1998. Animal feedstuffs, animal products, and feces or urine-Determina- tion of gross calorific values-Bomb calorimeter method. International Organization for Standardization.

International Organization for Standardization. 2005. ISO 5983:2005. Animal feeding stuffs. Determination of nitrogen content and calculation of crude protein content-Part 1: Kjeldahl method. International Standards Organization.

International Organization for Standardization. 2013. ISO 9622:2013. Milk and liquid milk products. Guidelines for the application of mid-infrared spectrometry. International Standards Organization.

Kim, H., H. G. Lee, Y. C. Baek, S. Lee, and J. Seo. 2020. The effects of dietary supplementation with 3-nitrooxypropanol on enteric methane emissions, rumen fermentation, and production performance in ruminants: A meta-analysis. J. Anim. Sci. Technol. 62:31-42. https://doi.org/10.5187/jast.2020.62.1.31.

Kliem, K. E., R. Morgan, D. J. Humphries, K. J. Shingfield, and D. I. Givens. 2008. Effect of replacing grass silage with maize silage in the diet on bovine milk fatty acid composition. Animal 2:18501858. https://doi.org/10.1017/S1751731108003078.

Klop, G., B. Hatew, A. Bannink, and J. Dijkstra. 2016. Feeding nitrate and docosahexaenoic acid affects enteric methane production and milk fatty acid composition in lactating dairy cows. J. Dairy Sci. 99:1161-1172. https://doi.org/10.3168/jds.2015-10214.

Lock, A. L., and K. J. Shingfield. 2004. Optimising milk composition. Pages 107-188 in Dairying: Using Science to Meet Consumers's Needs. E. Kebreab, J. Mills, D. E. Beever, ed. Nottingham University Press.

Lopes, J. C., L. F. de Matos, M. T. Harper, F. Giallongo, J. Oh, D. Gruen, S. Ono, M. Kindermann, S. Duval, and A. N. Hristov. 2016. Effect of 3-nitrooxypropanol on methane and hydrogen emissions, methane isotopic signature, and ruminal fermentation in dairy cows. J. Dairy Sci. 99:5335-5344. https://doi.org/10.3168/jds.2015 -10832 .

Manafiazer, G., S. Zimmerman, and J. A. Basarab. 2017. Repeatability and variability of short-term spot measurement of methane and carbon dioxide emissions from beef cattle using GreenFeed emissions monitoring system. Can. J. Anim. Sci. 97:118-126.

Martin, C., D. P. Morgavi, and M. Doreau. 2010. Methane mitigation in ruminants: From microbe to the farm scale. Animal 4:351-365. https://doi.org/10.1017/S1751731109990620.

McAllister, T. A., and C. J. Newbold. 2008. Redirecting rumen fermentation to reduce methanogenesis. Aust. J. Exp. Agric. 48:7-13. https://doi.org/10.1071/EA07218.

Melgar, A., M. T. Harper, J. Oh, F. Giallongo, M. E. Young, T. L. Ott, S. Duval, and A. N. Hristov. 2020b. Effects of 3-nitrooxypropanol on rumen fermentation, lactational performance, and resumption of ovarian cyclicity in dairy cows. J. Dairy Sci. 103:410-432. https: //doi.org/10.3168/jds.2019-17085.

Melgar, A., C. F. A. Lage, K. Nedelkov, S. E. Räisänen, H. Stefenoni, M. E. Fetter, X. Chen, J. Oh, S. Duval, M. Kindermann, N. D Walker, and A. N. Hristov. 2021. Enteric methane emission, milk production, and composition of dairy cows fed 3-nitrooxypropanol. J. Dairy Sci. 104:357-366. https://doi.org/10.3168/jds.2020 -18908 .

Melgar, A., K. C. Welter, N. Nedelkov, C. M. M. R. Martins, M. T. Harper, J. Oh, S. E. Räisänen, X. Chen, S. F. Cueva, S. Duval, and A. N. Hristov. 2020a. Dose-response effect of 3-nitrooxypropanol on enteric methane emissions in dairy cows. J. Dairy Sci. 103:6145-6156. https://doi.org/10.3168/jds.2019-17840.

Morgavi, D. P., E. Forano, C. Martin, and C. J. Newbold. 2010. Microbial ecosystem and methanogenesis in ruminants. Animal 4:10241036. https://doi.org/10.1017/S1751731110000546.

Muetzel, S., K. Lowe, P. H. Janssen, D. Pacheco, N. Bird, N. Walker, O. Vidoni, L. Schweikert, L. Clasadonte, and M. Kindermann. 2019. Towards the application of 3-nitrooxypropanol in pastoral farming systems. Page 81 in Proceedings of the 7th Greenhouse Gas and Animal Agriculture Conference. Iguassu Falls, Brazil. (Abstr.)

Nielsen, T. S., E. M. Straarup, M. Vestergaard, and K. Sejrsen. 2006. Effect of silage type and concentrate level on conjugated linoleic acids, trans-C18:1 isomers and fat content in milk from dairy 
cows. Reprod. Nutr. Dev. 46:699-712. https://doi.org/10.1051/ rnd:2006044.

Reynolds, C. K., D. J. Humphries, P. Kirton, M. Kindermann, S. Duval, and W. Steinberg. 2014. Effects of 3-nitrooxypropanol on methane emission, digestion, and energy and nitrogen balance of lactating dairy cows. J. Dairy Sci. 97:3777-3789. https://doi.org/ $10.3168 /$ jds.2013-7397.

Stocks, S. E., and M. S. Allen. 2012. Hypophagic effects of propionate increase with elevated hepatic acetyl coenzyme A concentration for cows in the early postpartum period. J. Dairy Sci. 95:32593268. https://doi.org/10.3168/jds.2011-4991.

Tyrrell, H. F., and J. T. Reid. 1965. Prediction of the energy value of cow's milk. J. Dairy Sci. 48:1215-1223. https://doi.org/10.3168/ jds.S0022-0302(65)88430-2.

Van Duinkerken, G., M. C. Blok, A. Bannink, J. W. Cone, J. Dijkstra, A. M. van Vuuren, and S. Tamminga. 2011. Update of the Dutch protein evaluation system for ruminants: The DVE/ OEB2010 system. J. Agric. Sci. 149:351-367. https://doi.org/10 .1017/S0021859610000912.

Van Es, A. J. H. 1978. Feed evaluation for ruminants. I. The systems in use from May 1977-onwards in the Netherlands. Livest. Prod. Sci. 5:331-345. https://doi.org/10.1016/0301-6226(78)90029-5.

van Gastelen, S. 2022a. Supplementary Figure S1 and S2 - JDS20782 - GreenFeed visits. Mendeley Data. V1. https://doi.org/10.17632/ 2nfwrtc44s.1.

van Gastelen, S. 2022b. Supplementary Tables S1 and S2 - JDS20782 - Milk fatty acid composition, Mendeley Data. V1. https://doi. org/10.17632/98ybrw5zjw.1.

van Gastelen, S., E. C. Antunes-Fernandes, K. A. Hettinga, G. Klop, S. J. J. Alferink, W. H. Hendriks, and J. Dijkstra. 2015. Enteric methane production, rumen volatile fatty acid concentrations, and milk fatty acid composition in lactating Holstein-Friesian cows fed grass silage- or corn silage-based diets. J. Dairy Sci. 98:1915-1927. https://doi.org/10.3168/jds.2014-8552.

van Gastelen, S., and J. Dijkstra. 2016. Prediction of methane emission from lactating dairy cows using milk fatty acids and midinfrared spectroscopy. J. Sci. Food Agric. 96:3963-3968. https://doi .org/10.1002/jsfa.7718.

van Gastelen, S., J. Dijkstra, and A. Bannink. 2019. Are dietary strategies to mitigate enteric methane emission equally effective across dairy cattle, beef cattle, and sheep? J. Dairy Sci. 102:6109-6130. https://doi.org/10.3168/jds.2018-15785.

van Gastelen, S., J. Dijkstra, G. Binnendijk, S. M. Duval, J. M. L. Heck, M. Kindermann, T. Zandstra, and A. Bannink. 2020. 3-Nitrooxypropanol decreases methane emissions and increases hy- drogen emissions of early lactation dairy cows, with associated changes in nutrient digestibility and energy metabolism. J. Dairy Sci. 103:8074-8093. https://doi.org/10.3168/jds.2019-17936.

Van Kessel, J. A. S., and J. B. Russell. 1996. The effect of pH on ruminal methanogenesis. FEMS Microbiol. Ecol. 20:205-210. https:/ /doi.org/10.1111/j.1574-6941.1996.tb00319.x.

van Lingen, H. J., J. E. Edwards, J. D. Vaidya, S. van Gastelen, E. Saccenti, B. van den Bogert, A. Bannink, H. Smidt, C. M. Plugge, and J. Dijkstra. 2017. Diurnal dynamics of gaseous and dissolved metabolites and microbiota composition in the bovine rumen. Front. Microbiol. 8:425. https://doi.org/10.3389/fmicb .2017 .00425 .

van Soest, P. J. 1994. Nutritional Ecology of the Ruminant. 2nd ed. Cornell University Press.

Van Wesemael, D., L. Vandaele, B. Ampe, H. Cattrysse, S. Duval, M. Kindermann, V. Fievez, S. De Campeneere, and N. Peiren. 2019. Reducing enteric methane emissions from dairy cattle: Two ways to supplement 3-nitrooxypropanol. J. Dairy Sci. 102:1780-1787. https://doi.org/10.3168/jds.2018-14534.

Vlaeminck, B., V. Fievez, A. R. J. Cabrita, A. J. M. Fonseca, and R. J. Dewhurst. 2006. Factors affecting odd- and branched-chain fatty acids in milk: A review. Anim. Feed Sci. Technol. 131:389-417. https://doi.org/10.1016/j.anifeedsci.2006.06.017.

Vyas, D., S. M. McGinn, S. M. Duval, M. K. Kindermann, and K. A. Beauchemin. 2018. Optimal dose of 3-nitrooxypropanol for decreasing enteric methane emissions from beef cattle fed high-forage and high-grain diets. Anim. Prod. Sci. 58:1049-1055. https://doi .org/10.1071/AN15705.

Zimmerman, P., S. Zimmerman, S. Utsumi, and D. Beede. 2011. Development of a user friendly online system to quantitatively measure metabolic gas fluxes from ruminants. J. Dairy Sci. 94(ESuppl. 1):760.

\section{ORCIDS}

Sanne van Gastelen () https://orcid.org/0000-0003-4547-8449 Jan Dijkstra ( https://orcid.org/0000-0003-3728-6885

Jeroen M. L. Heck (ํ) https://orcid.org/0000-0001-6772-2495

Maik Kindermann @ https://orcid.org/0000-0002-2854-286X

Arie Klop @ https://orcid.org/0000-0001-8842-9562

Rudi de Mol $\odot$ https://orcid.org/0000-0003-4372-401X

André Bannink @ https://orcid.org/0000-0001-9916-3202 